\title{
Response of juvenile progeny of seven forest tree species and their populations to simulated climate change-related stressors, heat, elevated humidity and drought
}

\author{
Alfas Pliūra ${ }^{(1-2)}$, \\ Jurga Jankauskiené ${ }^{(3-4)}$, \\ Vaidotas Lygis ${ }^{(3-5)}$, \\ Vytautas Suchockas ${ }^{(1-2)}$, \\ Gintare Bajerkevičiené ${ }^{(1)}$, \\ Rita Verbylaitè ${ }^{(1)}$
}

The study aimed to evaluate response and phenotypic plasticity of juvenile progeny of seven forest tree species Pinus sylvestris, Picea abies, Quercus robur, Fraxinus excelsior, Alnus glutinosa, Betula pendula and Populus tremula and their populations to climate change-related stressors, simulated in a phytotron - heat and elevated humidity and heat and drought - in comparison to performance in ambient (control) conditions. Treatment effect on sapling morphometric, physiological and biochemical traits was significant except for health condition, transpiration and photosynthetic rates and water use efficiency (WUE). Species effect and species-by-treatment interaction were strongly significant in most traits studied, indicating a great inter-specific variability of responses to the applied treatments. Compared to control, stem diameter increment was lower for most species following both hot-wet and hotdry treatments, while treatment impact on height increment was less pronounced and sometimes even positive. Drought caused significant defoliation in $P$. tremula, $A$. glutinos $a$ and $B$. pendula, while under hot-wet treatment the defoliation in most species was lower than in control. Following hot dry treatment, WUE in $P$. abies, $P$. sylvestris and $B$. pendula was lower than following both hot-wet treatment and control, while in $P$. tremula, A. glutinosa and $Q$. robur WUE was higher. This suggests that the latter species are able to maintain a balance between photosynthesis and transpiration. Photosynthetic rate was highest in $P$. tremula, $B$. pendula and $A$. glutinosa, however it was much more negatively affected by water deficit in these three species than in other tested species. In most cases, drought had a negative effect on production of pigments in deciduous tree species, which, together with increased amounts of malondialdehyde and hydrogen peroxide, indicated a presence of an oxidative stress. Significant population effect and population-by-treatment interactions found for most traits showed different plasticity and response of tree populations to the treatments. Although, only $19 \%$ of the populations showed significant ecovalencies. Some of the observed reactions may not be considered as adaptive acclimation as decreasing growth of some species and populations indicates deteriorating performance which may lead to changes in their competitiveness, thus compromising regeneration, persistence of natural successions and sustainability of forest ecosystems.

Keywords: Climate Change, Stress, Growth, Physiology, Transpiration, Photosynthesis, Water Use Efficiency, Biochemical Parameters, Phenotypic Plasticity

\section{Introduction}

Over the few last millennia forest tree species were subjected to conspicuous climatic and environmental changes and were forced to react to these changes by migration and genetic adaptation to new growing conditions (Huntley \& Birks 1983). Current environmental changes are significantly faster compared to those that took place during post-glacial climatic shifts. Therefore, there are widespread concerns that trees, as long-lived organisms, may not be able to cope with rapid climate changes. Increasing frequency and amplitude of abiotic and biotic disturbances driven by recent rapid climate change may compromise the sustainability of forest ecosystems, forest regeneration, biodiver- sity and persistence of natural ecological successions in European boreal and northern temperate forests. Global climate changes are leading to increase in temperature as well as alterations in rainfall patterns (Bhargava \& Sawant 2013, Shah 2015).

With prolonged periods of drought and temperature extremes becoming more frequent (Kattenberg et al. 1996), the environmental stress on trees will increase. For example, in Lithuania, there were several local and country-wide periods of prolonged drought and heat waves/temperature extremes $\left(>+30^{\circ} \mathrm{C}\right)$ during the last two decades (1995-2015). These climatic extremes occurred about three times more often than during the preceding two de- 
cades (1975-1995): during 1995-2015 there were 102 days with day temperatures exceeding $+30^{\circ} \mathrm{C}$, during 1975-1995 there were only 35 such days (Anonymous 2017). Changes in physical climate will subsequently induce changes in plant morphology, physiology and chemistry that may increase plant susceptibility to diseases (Chakraborty et al. 2000). The risk of drought increases in some regions because of reduced soil moisture caused by enhanced evapotranspiration under a rising temperature (Mitchell et al. 1990). Such changes have the potential to directly affect the physiological processes of plants such as photosynthesis and transpiration (Norby et al. 1999). Water deficit is regarded to be a major factor limiting plant growth (Hsiao 1973, Rhodenbaugh \& Pallardy 1993). Drought is one of the most important abiotic stress factors that influence the natural distribution of woody plants and limit ecosystem production (Yang \& Miao 2010). Recent studies demonstrated that drought affects a wide range of plant responses, from changes in plant metabolism to the alteration in leaf and wood anatomy (Topić et al. 2013, Stojnić et al. 2016). High temperature and drought stresses alter the physiological, biochemical and molecular responses of plants (Wahid et al. 2007, Song et al. 2014). These stresses increase tree mortality world-wide revealing climate change risk for forests (Allen et al. 2010).

Photosynthetic rate is considered to be a sensitive physiological parameter of plant metabolism and development which can be measured and used to reflect plant response to changes in environmental conditions and to evaluate the resistance of tree populations to drought and high temperatures (Liu et al. 2013, Ma et al. 2014). Induced inhibition of photosynthesis and oxidative stress well reveal the effect of lack of water in the cell, reducing plant dry biomass accumulation and productivity (Griffin et al. 2004, Wahid et al. 2007, Zhao et al. 2014). It has been demonstrated that the inhibition of photosynthesis and magnitude of oxidative stress strength largely depends on stomatal conductivity (Bacelar et al. 2007, Medrano et al. 2015). Initial response to the reduced amount of water in soil is stomatal closure, which decreases evaporation, gas exchange intensity and intercellular $\mathrm{CO}_{2}$ concentration, thus reducing photosynthetic productivity (Bacelar et al. 2007, Song et al. 2014). Severe drought during one growing season may induce physiological responses that are carried over into the following years (Irvine et al. 1998).

Generation of reactive oxygen species (ROS) is one of the earliest responses of plant cells to heat and drought stresses. Moreover, free radicals damage plant cellular macromolecules, biomembranes and increase lipid peroxidation (Bacelar et al. 2007, Cheeseman 2007). On the other hand, they also play a signaling role, and changes in production of ROS can act as a signal that changes the transcription of genes, thereby favoring the adaptation of plants to stresses (Jajic et al. 2015). Among ROS species, the hydrogen peroxide $\left(\mathrm{H}_{2} \mathrm{O}_{2}\right)$ is an important compound involved in plant response to different environmental stressors (Belkadhi et al. 2014, Jajic et al. 2015). Moreover, $\mathrm{H}_{2} \mathrm{O}_{2}$ protects photosynthetic membranes during light stress (Laloi et al. 2007). Lipid peroxidation is well-established mechanism of controlling cellular injures in both plants and animals, and is used as an indicator of oxidative stress in cells and tissues (Dalle-Donne et al. 2003). Malondialdehyde (MDA) is usually used to evaluate status of redox and osmotic adjustment, which is important in the adaptation of plants to environmental stresses. A lower MDA gives indication of a higher anti-oxidative ability (high oxidative stress tolerance), which reflects a higher drought resistance (Apel \& Hirt 2004).

Plant pigments are of key importance for photosynthetic processes and for preventing photo-oxidation and photo-inhibition (García-Plazaola \& Becerril 2000). The decrease of chlorophyll content is a typical symptom of oxidative stress (Bacelar et al. 2007, Morais et al. 2007). Photosynthetic pigments are important to plants mainly for harvesting light and for the production of reducing molecules such as ATP and NADPH. Plants respond to changing environmental conditions by changes in composition of pigments in the chloroplasts (Morais et al. 2007). For proper functioning of the photosynthetic mechanism, the chlorophyll $a / b$ ratio may decrease in leaves because chlorophyll $a$ has a tendency to degrade faster in stressful conditions than chlorophyll $b$ (Morais et al. 2007). Carotenoids are also present in plant cellular membranes and protect the membranes from light-dependent oxidative damage (Morais et al. 2007, Zhang et al. 2008). Comparison of drought-tolerant and sensitive cultivars of herbaceous species suggested that tolerance positively correlates with concentration of carotenoids in plant tissues (Davison et al. 2002, Zhang et al. 2008).

Such a high pressure by climate changerelated stressors may not only affect plant physiology, but also through an intensified natural selection may result in changes in plants' genetic properties, reduction of genetic diversity and, subsequently, decline in adaptability potential of plant populations (Koskela \& Lefèvre 2013). The wide distribution of temperate and boreal forest tree species throughout Europe exposed them to a variety of environmental conditions. Such a capacity for the dynamic colonisation has been attributed to a large species' adaptability (Eriksson 1998). Previous studies have shown a large variation in forest trees' responses to changing environmental conditions or impact by various climate change-related stressors (Dormling et al. 1968, Skre 1991, Weiser 1995, Kleinschmit et al. 1996, Clapham et al. 1998, Baliuckas
2002, Pliura \& Eriksson 2002, Pliura \& Kundrotas 2002, Baliuckas \& Pliura 2003, Lauteri et al. 2004, Eriksson et al. 2005, Pliura \& Baliuckas 2007, Pliura et al. 2008, 2016, Petrokas \& Pliura 2014). Ecophysiological studies highlighted differential mechanisms of response to water stress depending on site conditions at the origins (Lauteri et al. 1997a, 1997b, 2004). A higher capacity of photosynthesis and transpiration in seedlings originating from arid sites than in those from mesic sites was reported (Lauteri et al. 1999). Studies on genetic variation in these traits in material from the whole distribution area of a certain tree species indicated a presence of amongand within-population genetic variation in drought tolerance (Pliura \& Eriksson 2002, Lauteri et al. 2004). It has been found that different populations and genotypes show different plasticity and patterns of response to stressors. This builds a basis for a natural selection to act upon and loss of less adaptive genotypes may change a genotypic structure and reduce genetic diversity of populations. These may have a negative effect on evolution and survival of separate populations or even of the entire species. Under climate change temperate deciduous forests are predicted to shift northwards, where they are likely to replace mixed forests (Bachelet et al. 2001). Lithuania is located in the transition between the continental and boreal biogeographical regions of Europe - continental and boreal (EEA 2002) - thus northwards shifting of climatic envelope may have more pronounced impact on those forest ecosystems than in centres of biogeographical regions.

Despite extensive research efforts there is still a certain lack of knowledge on how different tree species and populations may respond to rapidly changing environmental conditions and extreme climate change-related stressors, what are the mechanisms of species' adaptation, which species have developed best strategies to cope with the stress-induced damages, and how adaptive response and phenotypic plasticity can contribute to adaptation to stressful environmental conditions. The aim of the present study was to evaluate response and plasticity of juvenile progeny of seven forest tree species, Scots pine, Norway spruce, pedunculate oak, common ash, black alder, silver birch and common aspen, and their different populations to climate change-related stressors - heat in combination with drought or elevated humidity - simulated in a controlled environment. A complex of morphometric (tree height and diameter), health condition (survival, sanitary condition and defoliation), physiological (rate of photosynthesis as net $\mathrm{CO}_{2}$ assimilation, transpiration, stomatal conductance and intercellular $\mathrm{CO}_{2}$ concentration, rate of photosynthetic gas exchange) and biochemical parameters (amount of photosynthetic pigments, stress-indicating biochemical compounds 
like hydrogen peroxide and malondialdehyde) were used as indicators of response variability among species and populations.

\section{Materials and methods}

\section{Tree species studied}

Saplings of seven forest tree species (Scots pine, Pinus sylvestris L.; Norway spruce, Picea abies [L.] Karst.; pedunculate oak, Quercus robur L.; European ash, Fraxinus excelsior L.; black alder, Alnus glutinosa [L.] Gaertn.; silver birch, Betula pendula Roth.; and common aspen, Populus tremula L.) were used in the present study. Each species was represented by open-pollinated progenies from three populations representing three different ecoclimatic subregions of Lithuania and two biogeographical regions of Europe - continental and boreal (EEA 2002 - Tab. 1).

\section{Treatment experiments}

Prior to the treatment experiments, the saplings of all tree species except common aspen were grown in an open-air nursery, and in autumn 2015 they were transplanted into plastic squared pots $(15 \times 15 \times 17 \mathrm{~cm})$ filled with 3.5 I of peat substratum (Klasmann KTS-1, pH 5.5-6.0, with $\mathrm{N} 140 \mathrm{mg} \mathrm{l}^{-1}$, $\mathrm{P}_{2} \mathrm{O}_{5} 160 \mathrm{mg} \mathrm{l}^{-1}, \mathrm{~K}_{2} \mathrm{O} 18 \mathrm{mg} \mathrm{l}^{-1}, \mathrm{Mg} 85 \mathrm{mg} \mathrm{l}^{-1}$ ). Each treatment was performed using a randomized complete block design with 27 single-tree plots of each population. Two such blocks were established. In total, over 5000 saplings of all the tested tree species were used in this experiment.

The experiments were carried out in two closed walk-in chambers of greenhouse type with semi-controlled environment in a phytotron of the Institute of Forestry, Lithuanian Research Centre for Agriculture and Forestry (Central Lithuania, $55^{\circ} 52^{\prime} \mathrm{N}$ $24^{\circ} 07^{\prime} \mathrm{E}$ ). The area of each chamber covered $60 \mathrm{~m}^{2}$ and the interior volume was $240 \mathrm{~m}^{3}$. Two treatments were set to mimic forecasted stressors of climate change (namely, heat and drought, and heat and elevated humidity), and the third was control (ambient conditions). Specifically, the treatments were:

(1) Hot-wet (HW) treatment. Air temperature ranged between 25 and $40{ }^{\circ} \mathrm{C}$ during day and between 15 and $20^{\circ} \mathrm{C}$ during night, and air humidity during day ranged between 60 and $80 \%$. Plants were watered as necessary throughout the experiment. The total duration of the hot-wet treatment was two months (July and August).

(2) Hot-dry (HD) treatment. In mid-July 2016, artificial drought conditions have been created by reducing watering of tree saplings for three weeks and keeping substrate moisture at $20-30 \%$ of the total water holding capacity. To estimate soil water content, evapotranspiration and plant water status, in each treatment, 15 pots with substrate and saplings of each tree species ( 5 per population) were weighted every second day, allowing the estimation of water loss in the pots at a given moment. The

Tab. 1 - Data on origin of populations of seven forest tree species used in the experiment. (a): http://www.geoportal.It (2016); (b): Chromov (1968); (c): EEA (2002).

\begin{tabular}{|c|c|c|c|c|c|c|c|c|}
\hline $\begin{array}{l}\text { Tree } \\
\text { species }\end{array}$ & Population & $\begin{array}{l}\text { Long } \\
\text { Lat }\end{array}$ & 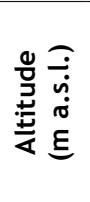 & 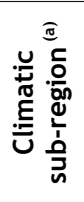 & 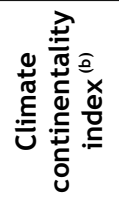 & 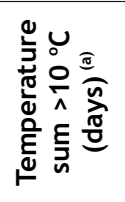 & 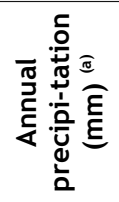 & 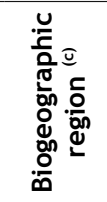 \\
\hline \multirow{3}{*}{$\begin{array}{l}\text { Pinus } \\
\text { sylvestris }\end{array}$} & Jonava & $\begin{array}{l}55^{\circ} 01^{\prime} \mathrm{N} \\
24^{\circ} 28^{\prime} \mathrm{E}\end{array}$ & 40 & 6 & 30 & 2200 & 620 & Contin. \\
\hline & Varena & $\begin{array}{l}54^{\circ} 04^{\prime} \mathrm{N} \\
24^{\circ} 30^{\prime} \mathrm{E}\end{array}$ & 125 & 9 & 31 & 2170 & 650 & Contin. \\
\hline & Anykščiai & $\begin{array}{l}55^{\circ} 38^{\prime} \mathrm{N} \\
25^{\circ} 06^{\prime} \mathrm{E}\end{array}$ & 120 & 8 & 30 & 2150 & 700 & Boreal \\
\hline \multirow{3}{*}{$\begin{array}{l}\text { Picea } \\
\text { abies }\end{array}$} & Rietavas & $\begin{array}{l}55^{\circ} 32^{\prime} \mathrm{N} \\
22^{\circ} 24^{\prime} \mathrm{E}\end{array}$ & 140 & 5 & 26 & 2000 & 850 & Boreal \\
\hline & Kaunas & $\begin{array}{l}54^{\circ} 59^{\prime} \mathrm{N} \\
23^{\circ} 55^{\prime \prime} \mathrm{E}\end{array}$ & 74 & 7 & 30 & 2220 & 640 & Contin. \\
\hline & Anykščiai & $\begin{array}{l}55^{\circ} 32^{\prime} \mathrm{N} \\
24^{\circ} 59^{\prime} \mathrm{E}\end{array}$ & 125 & 8 & 30 & 2150 & 700 & Boreal \\
\hline \multirow{3}{*}{$\begin{array}{l}\text { Quercus } \\
\text { robur }\end{array}$} & Tytuvenai & $\begin{array}{l}55^{\circ} 39^{\prime} \mathrm{N} \\
23^{\circ} 01^{\prime} \mathrm{E}\end{array}$ & 122 & 5 & 27 & 2100 & 700 & Boreal \\
\hline & Jonava & $\begin{array}{l}55^{\circ} 05^{\prime} \mathrm{N} \\
24^{\circ} 15^{\prime} \mathrm{E}\end{array}$ & 90 & 6 & 30 & 2200 & 620 & Contin. \\
\hline & Anykščiai & $\begin{array}{l}55^{\circ} 33^{\prime} \mathrm{N} \\
24^{\circ} 55^{\prime} \mathrm{E}\end{array}$ & 103 & 8 & 30 & 2150 & 700 & Boreal \\
\hline \multirow{3}{*}{$\begin{array}{l}\text { Fraxinus } \\
\text { excelsior }\end{array}$} & Bartoszyce & $\begin{array}{l}54^{\circ} 13^{\prime} \mathrm{N} \\
20^{\circ} 46^{\prime} \mathrm{E}\end{array}$ & 72 & 9 & 31 & 2400 & 700 & Contin. \\
\hline & Lelkovo & $\begin{array}{l}54^{\circ} 15^{\prime} \mathrm{N} \\
20^{\circ} 11^{\prime} \mathrm{E}\end{array}$ & 111 & 9 & 31 & 2400 & 700 & Contin. \\
\hline & Kozlovo & $\begin{array}{l}53^{\circ} 31^{\prime} \mathrm{N} \\
20^{\circ} 22^{\prime} \mathrm{E}\end{array}$ & 339 & 9 & 31 & 2300 & 700 & Contin. \\
\hline \multirow{3}{*}{$\begin{array}{l}\text { Betula } \\
\text { pendula }\end{array}$} & Raseiniai & $\begin{array}{l}55^{\circ} 20^{\prime} \mathrm{N} \\
22^{\circ} 57^{\prime} \mathrm{E}\end{array}$ & 110 & 7 & 28 & 2070 & 700 & Contin. \\
\hline & Ukmerge & $\begin{array}{l}55^{\circ} 22^{\prime} \mathrm{N} \\
24^{\circ} 32^{\prime} \mathrm{E}\end{array}$ & 126 & 6 & 30 & 2200 & 630 & Boreal \\
\hline & Anykščiai & $\begin{array}{l}55^{\circ} 40^{\prime} \mathrm{N} \\
25^{\circ} 10^{\prime} \mathrm{E}\end{array}$ & 113 & 8 & 30 & 2150 & 700 & Boreal \\
\hline \multirow{3}{*}{$\begin{array}{l}\text { Alnus } \\
\text { glutinosa }\end{array}$} & Tytuvenai & $\begin{array}{l}55^{\circ} 34^{\prime} \mathrm{N} \\
23^{\circ} 18^{\prime} \mathrm{E}\end{array}$ & 131 & 5 & 27 & 2100 & 700 & Boreal \\
\hline & Jonava & $\begin{array}{l}55^{\circ} 00^{\prime} \mathrm{N} \\
24^{\circ} 15^{\prime} \mathrm{E}\end{array}$ & 61 & 6 & 30 & 2200 & 620 & Contin. \\
\hline & Valkininkai & $\begin{array}{l}54^{\circ} 24^{\prime} \mathrm{N} \\
24^{\circ} 34^{\prime} \mathrm{E}\end{array}$ & 159 & 9 & 31 & 2150 & 670 & Boreal \\
\hline \multirow{3}{*}{$\begin{array}{l}\text { Populus } \\
\text { tremula }\end{array}$} & Tytuvenai & $\begin{array}{l}55^{\circ} 37^{\prime} \mathrm{N} \\
23^{\circ} 21^{\prime} \mathrm{E}\end{array}$ & 110 & 5 & 27 & 2100 & 700 & Boreal \\
\hline & Dubrava & $\begin{array}{l}54^{\circ} 51^{\prime} \mathrm{N} \\
24^{\circ} 04^{\prime} \mathrm{E}\end{array}$ & 80 & 7 & 30 & 2210 & 650 & Contin. \\
\hline & Anykščiai & $\begin{array}{l}55^{\circ} 34^{\prime} \mathrm{N} \\
24^{\circ} 50^{\prime} \mathrm{E}\end{array}$ & 115 & 8 & 30 & 2150 & 700 & Boreal \\
\hline
\end{tabular}

water loss was calculated by comparing weight of these pots with that of the same pots with fully saturated substrate (weighted prior to treatment). When soil moisture for certain tree species dropped below $20 \%$ of the total water capacity, a limited irrigation (flooding) from below was applied. During the period of artificial drought, air humidity in the climatic chamber during day ranged between 40 and $60 \%$. After this treatment the plants were watered to restore full water holding capacity of peat substrate.

(3) Control (ambient conditions, Amb). Saplings were grown outside the phytotron in an open air. During the experiment, outside air temperature ranged between 20 and $28{ }^{\circ} \mathrm{C}$ during day and between 12 and $17{ }^{\circ} \mathrm{C}$ during night, and air humidity ranged between 60 and $80 \%$. Plants were watered when necessary throughout the experiment to keep substrate moisture in pots between 70 and $90 \%$ of full water holding capacity. The total duration of the control treatment was four months (MayAugust). In the year the present study was performed (2016), no natural droughts or heat waves have occurred at the experimental site, thus control treatment corresponded to ambient climatic conditions almost unaffected by climate change.

Temperature regimes were equal both in HW and HD treatments. In growth chambers, light intensity (PAR 400-700 nm) at the top of the sapling crowns in clear days

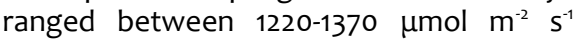
while in open air between 1670-2090 $\mu \mathrm{mol}$ $\mathrm{m}^{-2} \mathrm{~s}^{-1}$.

\section{Assessment of sapling morphometric and physiological parameters}

Total height (above the ground) and stem 
diameter at the root collar were measured for each sapling before and by the end of vegetation season of 2016. Height and diameter increments were calculated for each sapling based on their corresponding heights and diameters. Sapling health condition was scored in autumn 2016 using a categorical scale ranging from 5 (excellent condition, no visible damages) to 1 (very bad condition, dying). Survival was assessed in autumn 2016 as the ratio between a number of survived trees and the total number of alive trees at the beginning of vegetation season. Sapling defoliation (leaf/needle loss) was estimated as a fraction of shed leaves/needles at the end of each treatment of the initial amount of leaves/needles on a certain sapling (recorded at the beginning of the experiment).

Rates of photosynthesis as net $\mathrm{CO}_{2}$ assimilation $\left(A, \mu \mathrm{mol} \mathrm{m}^{-2} \mathrm{~s}^{-1}\right)$, transpiration $(E$,

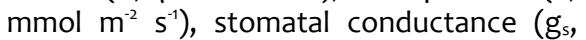
mol m $\left.\mathrm{m}^{-2} \mathrm{~s}^{-1}\right)$ and intercellular $\mathrm{CO}_{2}$ concentration $\left(\mathrm{Ci}, \mu \mathrm{mol} \mathrm{mol}{ }^{-1}\right)$ were recorded using a LCpro-SD $^{\oplus}$ portable photosynthesis system (ADC BioScientific Ltd, UK). Light conditions inside a leaf chamber were set using the LCpro-SD light unit, which emitted photosynthetically active radiation (PAR) at $1000 \mu \mathrm{mol} \mathrm{m} \mathrm{m}^{-2} \mathrm{~s}^{-1}$. The air supply unit provided a flow of ambient air to the leaf chamber at a constant rate of $200 \mu \mathrm{mol} \mathrm{s}^{-1}$. Air humidity was set at $20 \mathrm{mBar}$ of partial water pressure; temperature and $\mathrm{CO}_{2}$ concentration were at ambient levels. Readings were taken under steady-state conditions (after $1 \mathrm{~min}$ ). In each treatment, photosynthetic gas exchange was assessed for nine randomly selected trees of each of the seven species from each population (Tab. 1). For the gas exchange measurements we selected: (i) for deciduous trees, a fully expanded and exposed fifth leave from the top of the leader shoot of each sapling, and (ii) for conifers, all needles on the first (from tree top) lateral annual shoot of each sapling. The measurements were carried out at the end of experiment (beginning of August) from 10:00 to 14:30 a.m.

Instantaneous water use efficiency (WUE, $\mu \mathrm{mol} \mathrm{mmol}{ }^{-1}$ ) was computed as the ratio between net photosynthesis and transpiration $(\mathrm{A} / \mathrm{E})$, and intrinsic water use efficiency $\left(W^{\prime} E_{i}, \mu \mathrm{mol} \mathrm{mol}^{-1}\right.$ ) was computed as the ratio between net photosynthesis and stomatal conductance $\left(\mathrm{A} / \mathrm{g}_{\mathrm{s}}-\right.$ Farquhar et al. 1989).

To estimate sapling response to different stressors, the amounts of produced malondialdehyde (MDA), hydrogen peroxide $\left(\mathrm{H}_{2} \mathrm{O}_{2}\right)$, and photosynthetic pigments (chlorophylls $a$ and $b$ and carotenoids) were assessed. For analysis of MDA and $\mathrm{H}_{2} \mathrm{O}_{2}$, fresh leaf material $(0.5 \mathrm{~g})$ was homogenized using $5 \%(\mathrm{w} / \mathrm{v})$ trichloracetic acid (TCA). Lipid peroxidation was estimated as the amount of MDA produced by 2-thiobarbituric acid (TBA - Kramer et al. 1991). The homogenates were centrifuged at 12,130 $\mathrm{g}$ for 17 min, and $2.0 \mathrm{ml}$ of supernatant was added to $3.0 \mathrm{ml}$ of $20 \%(\mathrm{w} / \mathrm{v})$ TCA containing $0.50 \%$ $(w / v)$ TBA. The homogenates were incubated at $95^{\circ} \mathrm{C}$ for $30 \mathrm{~min}$ and subsequently cooled on ice. After cooling, the homogenates were centrifuged at 12,130 $\mathrm{g}$ for 17 min, and MDA content was determined by subtracting absorbance value recorded at $600 \mathrm{~nm}$ from the absorbance value recorded at $532 \mathrm{~nm}$ and using an absorbance coefficient of $155 \mathrm{mM}^{-1} \mathrm{~cm}^{-1} . \mathrm{H}_{2} \mathrm{O}_{2}$ content in leaves was determined according to Velikova et al. (2000). A $0.5 \mathrm{ml}$ of supernatant was added to $0.5 \mathrm{ml}$ of potassium phosphate buffer $(10 \mathrm{mM}, \mathrm{pH} 7.0)$ mixed with $1.0 \mathrm{ml}$ of potassium iodide $(1 \mathrm{M})$. The reaction solution was incubated for $30 \mathrm{~min}$ at $25^{\circ} \mathrm{C}$ in the dark. The absorbance of the supernatant was measured at $390 \mathrm{~nm}$ wavelength. The amount of $\mathrm{H}_{2} \mathrm{O}_{2}$ was calculated using a standard curve based on known concentrations.

The photosynthetic pigments were extracted from $0.05 \mathrm{~g}$ of fresh leaf/needle material in $3 \mathrm{ml}$ of $\mathrm{N}, \mathrm{N}^{\prime}$-dimethylformamide (DMF). The light absorption was measured at $480,664,647 \mathrm{~nm}$ wavelengths. Chlorophyll $a / b$ ratios and amounts of chlorophylls $a$ and $b$ and carotenoids were calculated according to Wellburn (1994).

All spectrophotometrical measurements were made using the spectrophotometer SPECORD $^{\oplus} 210$ Plus (Analytik Jena AG, Germany). All data are expressed on a leaf fresh weight basis.

\section{Statistical analysis}

The variance analysis of data was performed using the MIXED procedure in SAS (SAS ${ }^{\oplus}$ Analytics Pro 12.1, 9.3, SAS Institute Inc. 2016) which is based on Mixed model equations (MME) and restricted maximum likelihood (REML) method. The significance of fixed effects was tested using an F-test. The following linear models were used for joint analyses (eqn. 1) of all treatments together and for separate analyses (eqn. 2) of individual treatments:

$$
\begin{aligned}
Y_{i j k l m}= & \mu+T_{j}+S_{k}+P_{i(k)}+S_{i(k)} \cdot T_{j}+ \\
& P_{k} \cdot T_{j}+B_{m}+e_{i j k l m} \\
Y_{i k l m}= & \mu+S_{k}+P_{i(k)}+B_{m}+e_{i k l m}
\end{aligned}
$$

where $Y_{i \mathrm{iklm}}$ is an observation on $I^{\text {th }}$ tree from $i^{\text {th }}$ population in $k^{\text {th }}$ tree species in $m^{\text {th }}$ block in $j^{\text {th }}$ treatment, $Y_{\mathrm{iklm}}$ is an observation on $I^{\text {th }}$ tree from $i^{\text {th }}$ population in $k^{\text {th }}$ species in $m^{\text {th }}$ block, $\mu$ is the overall mean, $T_{j}$ is the effect of $j^{\text {th }}$ treatment, $B_{m}$ is the effect due to the $m^{\text {th }}$ block, $S_{k}$ is the effect due to the $k^{\text {th }}$ tree species, $P_{i(k)}$ is the effect of $i^{\text {th }}$ population in $k^{\text {th }}$ species, $P_{i(k)} \cdot T_{j}$ is the effect of interaction between $i^{\text {th }}$ population in $k^{\text {th }}$ species and $j^{\text {th }}$ treatment, $S_{k} \cdot T_{j}$ is the effect of interaction between $k^{\text {th }}$ species and $j^{\text {th }}$ treatment, $\varepsilon_{\mathrm{ijklm}}$ and $\varepsilon_{\mathrm{ik} \mid m}$ are the random residuals. The models assume that all effects are fixed.

Assumptions of normal distribution of residuals and variance homogeneity for each trait were tested by using the Shapiro- Wilk tests (Sabin \& Stafford 1990) with the GLM and UNIVARIATE procedures in SAS. Least-square means estimates were obtained for species and populations at each treatment and statistical significance (at $P<0.05$ ) of differences between leastsquares means was tested using a $t$-test. Pearson's correlation between growth, tree condition and physiological parameters were calculated for each tree species, SAS CORR procedure was used.

To evaluate the stability of individual populations across treatments (including control) and the contribution of each of the populations to the population $\times$ treatment interaction variances, the Wricke ecovalence values (Wricke 1962) were calculated using variances and least-square means obtained within each treatment with SAS MIXED procedure and expressed as a percent of the total population $\times$ treatment interaction variance. The Shukla stability variances were computed and the statistical significance of the ecovalences was tested using the F-test developed by Shukla (1972). In calculating ecovalences, to better fulfill the assumptions behind the linear model and thus to reduce scale effects of different treatments in joint analysis, the data were transformed to equal population variance. Phenotypic plasticity of each population was estimated as difference between maximum and minimum leastsquares means obtained across treatments.

In order to evaluate multidimensional differences among populations and among species based on the complex of tree growth, health condition, physiological and biochemical traits, a Rotated Principal Factor Analysis was performed on all data across all treatments using the FACTOR procedure in SAS software (SAS ${ }^{\circledast}$ Analytics Pro 12.1, 9.3, SAS Institute Inc 2016). SAS procedure SCORE was used to score population means based on output from FACTOR procedure. Its outputs were used to plot populations' means in coordinates of main factors applying the SAS procedure PLOT.

\section{Results}

\section{Treatment effect}

The results of multifactor analysis of variance using a statistical model (1) showed that the impact of treatment on sapling morphometric, physiological and biochemical traits was highly significant $(P<0.001)$ or significant $(P<0.01)$, except tree health condition, transpiration, photosynthetic rates and WUE (Tab. 2). Compared to control, stem diameter increment was lower in most tested tree species following both hot-wet and hot-dry treatments, while differences in height growth were less pronounced (Fig. 1). For most species this resulted in an increase of height to diameter ratio under both hot-wet and hot-dry conditions compared to control (Fig. 1C). In general, an increase in tree defoliation was observed in hot-dry conditions, and among 
Tab. 2 - Results from joint mixed linear model (eqn. 1) analysis of variance of different morphometric, health condition, physiological and biochemical traits in twenty one tested populations of seven forest tree species following hot-wet and hot-dry treatments and in ambient conditions (control): F-criteria and probabilities $(P)$ of the fixed effects. For the definition of traits, see Materials and Methods. (ne): Not estimated.

\begin{tabular}{|c|c|c|c|c|c|c|c|c|c|c|c|c|}
\hline \multirow[t]{2}{*}{ Trait } & \multicolumn{2}{|c|}{ Treatment } & \multicolumn{3}{|c|}{ Block } & Species & \multicolumn{2}{|c|}{ Populations } & \multicolumn{2}{|c|}{$\begin{array}{l}\text { Species } x \\
\text { treatment }\end{array}$} & \multicolumn{2}{|c|}{$\begin{array}{r}\text { Population } \times \\
\text { treatment }\end{array}$} \\
\hline & $\mathrm{F}$ & $\mathbf{P}$ & $\mathrm{F}$ & $\mathbf{P}$ & $\mathrm{F}$ & $\mathbf{P}$ & $\mathrm{F}$ & $\mathbf{P}$ & $F$ & $P$ & $F$ & $P$ \\
\hline Height increment (ZH) & 8.8 & $<0.001$ & 0.3 & 0.559 & 3471.1 & $<0.001$ & 71.6 & $<0.001$ & 5.0 & $<0.001$ & 2.1 & 0.001 \\
\hline Diameter increment (ZD) & 37.8 & $<0.001$ & 0.9 & 0.333 & 1891.4 & $<0.001$ & 11.5 & $<0.001$ & 3.9 & $<0.001$ & 2.1 & 0.001 \\
\hline $\mathrm{H} / \mathrm{D}$ ratio & 49.9 & $<0.001$ & 0.1 & 0.766 & 2249.2 & $<0.001$ & 18.4 & $<0.001$ & 11.2 & $<0.001$ & 1.8 & 0.005 \\
\hline Defoliation & 108.6 & $<0.001$ & 43.5 & $<0.001$ & 1018.1 & $<0.001$ & 22.4 & $<0.001$ & 29.9 & $<0.001$ & 3.0 & $<0.001$ \\
\hline Tree condition & 0.6 & 0.540 & 2.7 & 0.099 & 47.2 & $<0.001$ & 14.1 & $<0.001$ & 1.7 & 0.065 & 1.1 & 0.327 \\
\hline Survival & 7.0 & 0.001 & 0.1 & 0.708 & 18.1 & $<0.001$ & 7.1 & $<0.001$ & 2.3 & 0.007 & 0.5 & 0.994 \\
\hline Transpiration rate & 3.8 & 0.051 & ne & ne & 161.4 & $<0.001$ & 1.7 & 0.050 & 42.6 & $<0.001$ & 3.5 & $<0.001$ \\
\hline Stomatal conductance & 15.3 & $<0.001$ & ne & ne & 103.0 & $<0.001$ & 1.7 & 0.058 & 14.0 & $<0.001$ & 3.4 & $<0.001$ \\
\hline Photosynthetic rate & 1.4 & 0.232 & ne & ne & 92.0 & $<0.001$ & 4.6 & $<0.001$ & 10.7 & $<0.001$ & 3.8 & $<0.001$ \\
\hline WUE & 0.6 & 0.440 & ne & ne & 8.5 & $<0.001$ & 2.0 & 0.014 & 8.7 & $<0.001$ & 2.1 & 0.001 \\
\hline WUEi & 6.5 & 0.011 & ne & ne & 4.0 & 0.001 & 2.4 & 0.003 & 3.3 & $<0.001$ & 2.4 & $<0.001$ \\
\hline Chlorophyll $a$ & 3469.4 & $<0.001$ & ne & ne & 20794.3 & $<0.001$ & 846.9 & $<0.001$ & 445.8 & $<0.001$ & 292.7 & $<0.001$ \\
\hline Chlorophyll $b$ & 2528.9 & $<0.001$ & ne & ne & 6001.3 & $<0.001$ & 330.8 & $<0.001$ & 140.1 & $<0.001$ & 89.5 & $<0.001$ \\
\hline Chlorophyll $a / b$ ratio & 2251.8 & $<0.001$ & ne & ne & 441.2 & $<0.001$ & 109.0 & $<0.001$ & 41.3 & $<0.001$ & 29.4 & $<0.001$ \\
\hline Carotenoids & 550.7 & $<0.001$ & ne & ne & 11439.4 & $<0.001$ & 459.4 & $<0.001$ & 132.7 & $<0.001$ & 141.4 & $<0.001$ \\
\hline MDA & 1170.5 & $<0.001$ & ne & ne & 12166.8 & $<0.001$ & 279.3 & $<0.001$ & 693.7 & $<0.001$ & 228.5 & $<0.001$ \\
\hline $\mathrm{H}_{2} \mathrm{O}_{2}$ & 7761.9 & $<0.001$ & ne & ne & 32792.7 & $<0.001$ & 1813.5 & $<0.001$ & 955.4 & $<0.001$ & 704.7 & $<0.001$ \\
\hline
\end{tabular}

the most severely defoliated were three pioneer tree species $P$. tremula, A. glutinosa and B. pendula (Fig. 1d). Meanwhile, defoliation rates were lower under the hotwet treatment for most of the tested tree species.

Absence of significant treatment effect in variation of transpiration rate, photosyn- thetic rate and WUE (Tab. 2) may be explained by highly differing reaction of different tree species and populations to the treatments applied (Fig. 2a, Fig. 2b, Fig. 2c) which is indicated by highly significant species and species-by-treatment interaction effects (Tab. 2). For most tested species transpiration and photosynthetic rates were higher following hot-wet treatment than under the hot-dry treatment (Fig. 2a, Fig. 2b). Highly different reactions of the tested species were observed in the hotwet treatment, while under the hot-dry treatment all species showed lower transpiration and photosynthetic rates as compared to control (Fig. 2a, Fig. 2b). For WUE,
Fig. 1 - Performance of seven forest tree species following hot-wet, hot-dry and control (Ambient) treatments. (a) Tree height increment; (b) stem diameter increment; (c) tree

height to stem diameter ratio (H/D); (d) tree defoliation.
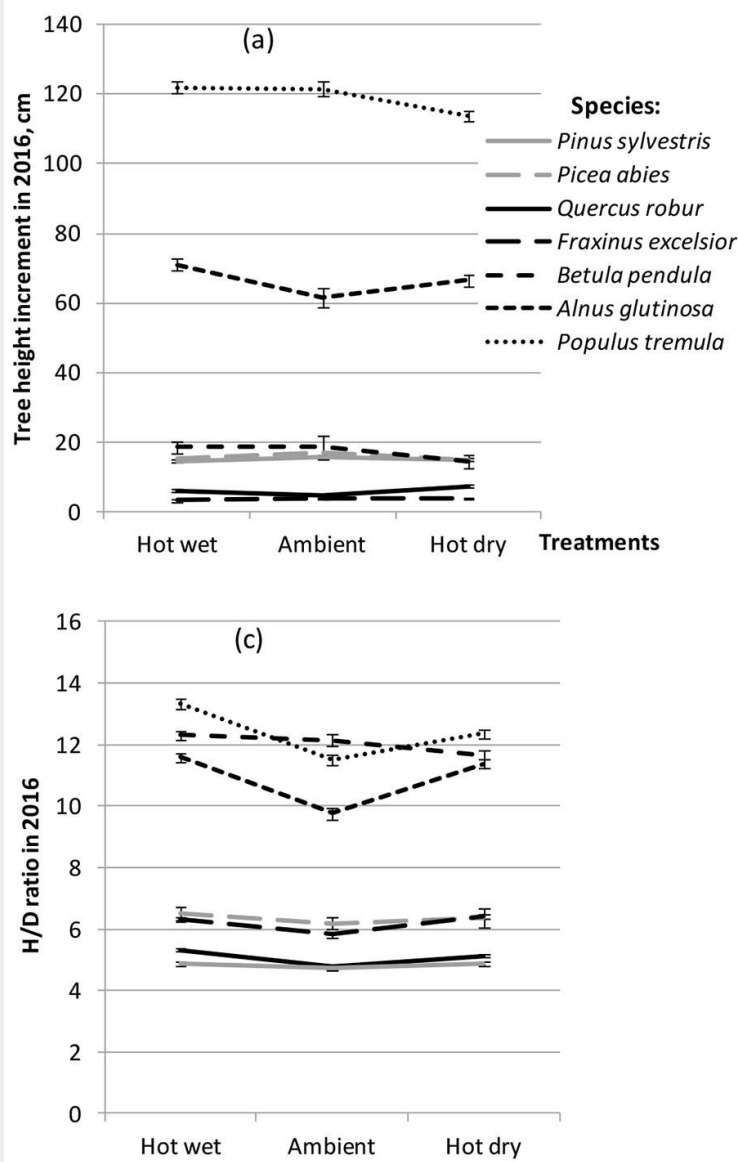
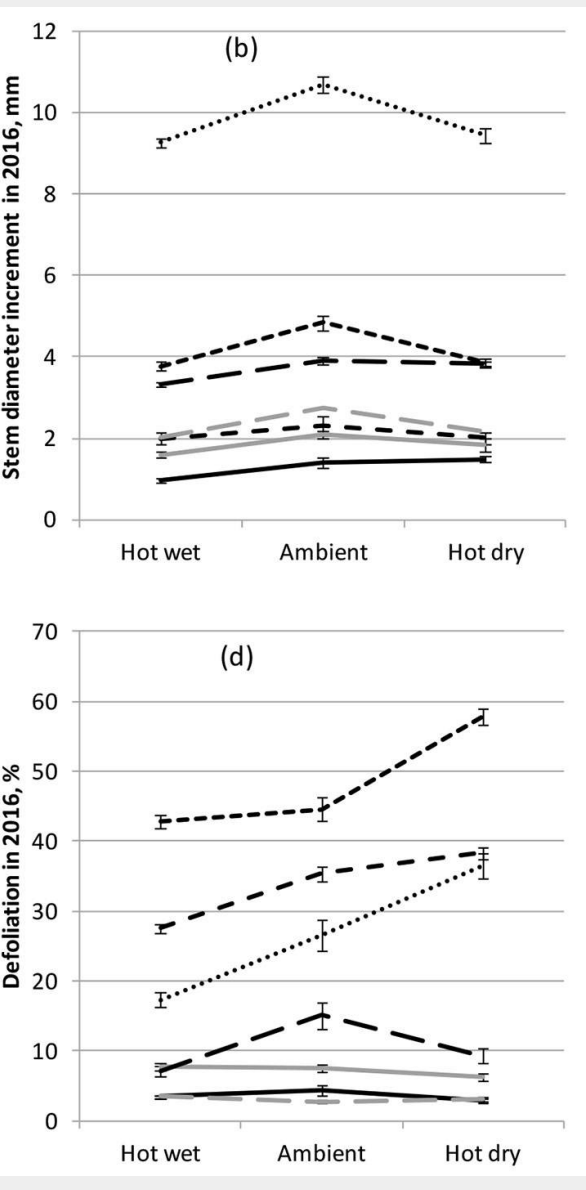

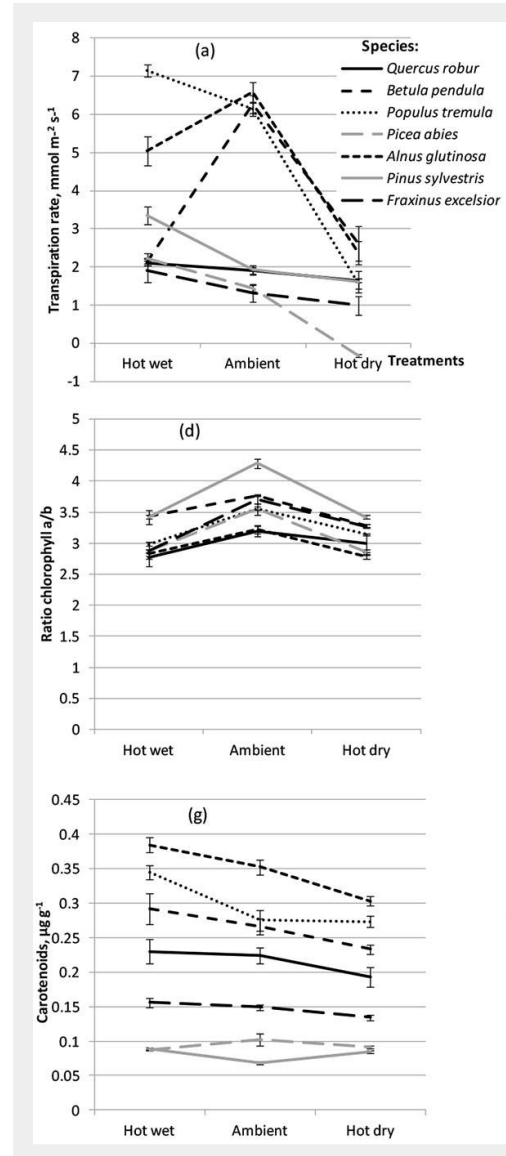

the reactions varied a lot among treatments and tree species (Fig. 2c). Compared to control, a clear reduction in chlorophyll $a / b$ ratio was observed following both hotwet and hot-dry treatments (Fig. 2d). Amounts of chlorophylls $a$ and $b$ as well as amount of carotenoids in leaves and needles in most tree species (except P. abies) under hot-wet conditions were greater than under ambient and hot-dry conditions (Fig. 2e-Fig. 2g).

Compared to control, the amount of MDA was greater under both hot-wet and hot-dry treatments in all tree species except F. excelsior; for F. excelsior MDA production was higher under hot-dry but lower under hot-wet conditions (Fig. 2h). Amount of $\mathrm{H}_{2} \mathrm{O}_{2}$ was lower following hotwet treatment (compared to control), while under hot-dry treatment it largely varied among different species. For example, $Q$. robur showed a clear reduction in production of $\mathrm{H}_{2} \mathrm{O}_{2}$ following both heat treatments, while both conifer species showed almost no reaction (Fig. 2i).

\section{Species effect}

ANOVA showed that species effect was highly significant $(P<0.001)$ for all the studied traits (Tab. 2). The largest height and diameter increments in all treatments were observed in fast growing deciduous tree species $P$. tremula and $A$. glutinosa (Fig. 1a, Fig. 1b). Height increment in these tree species varied from $113.6 \pm 1.4$ (mean \pm standard deviation) to $122.0 \pm 1.7 \mathrm{~cm}$ and from $66.5 \pm 1.7$ to $71.1 \pm 1.8 \mathrm{~cm}$, respec- tively. In noble hardwoods $Q$. robur and $F$. excelsior, height increment was much smaller and ranged between $4.6 \pm 0.4$ and $7.5 \pm 0.5 \mathrm{~cm}$ in Q. robur and between $3.3 \pm$ 0.3 and $3.9 \pm 0.4 \mathrm{~cm}$ in F. excelsior (Fig. 1a). Largest height to diameter ratio was observed for both these species and also for B. pendula (Fig. 1C). Nevertheless, A. glutinosa, $B$. pendula and $P$. tremula showed the highest degree of defoliation among all treatments (Fig. 1d). Rather intense defoliation of these species was observed even at ambient (control) conditions, which most likely was a result of the limited light availability because of close plant spacing.

Transpiration and photosynthetic rates were also the highest in P. tremula, B. pendula and A. glutinosa, although for all three species these parameters were much more affected by water deficit than for other investigated tree species (Fig. 2a, Fig. 2b).

The smallest, though significant, differences among the tested tree species were observed in chlorophyll $a / b$ ratio (Fig. $2 d$ ). Compared to control, very large differences among species were found in the amount of chlorophyll $a$, while for chlorophyll $b$ the differences were smaller (Fig. 2e, Fig. 2f). As regards species ranking, very similar pattern in the content of all pigments (chlorophylls $a$ and $b$ and carotenoids) were observed. For example, in A. glutinosa and $P$. tremula amounts of pigment were always the highest, while in $P$. sylvestris always the lowest, regardless the treatment. The highest amount of MDA was found in both noble hardwoods, Q. robur and $F$. excelsior, thus indicating the highest levels of lipid peroxidation as a response to oxidative stress, while the smallest MDA amount was in A. glutinosa and P. tremula (Fig. 2h). The highest amount of $\mathrm{H}_{2} \mathrm{O}_{2}$ was found in $\mathrm{F}$. excelsior and B. pendula followed by Q. robur, while the lowest amount was observed in both conifer species $P$. sylvestris and $P$. abies, regardless the treatment (Fig. 2i).

\section{Species-by-treatment interaction}

The species-by-treatment interaction was found to be significant $(P<0.05)$ for all studied traits except tree condition (Tab. 2). This interaction is manifested by differing patterns of reaction and species rank changes across treatments (Fig. 1, Fig. 2). The most variable species' performances across treatments were observed for transpiration rate, concentration of chlorophyll $a$, and amount of MDA and $\mathrm{H}_{2} \mathrm{O}_{2}$ (Tab. 2, Fig. 2a, Fig. 2e, Fig. 2h, Fig. 2i). Under the hot-dry treatment, most species showed slightly reduced height and stem diameter increments (compared to control); however, some species such as Q. robur for both height and stem diameter increment and A. glutinosa for height increment, showed opposite reactions (Fig. 1a, Fig. 1b). All tested tree species except Q. robur showed somehow lower stem diameter increment in both stressful environments as compared to ambient conditions (Fig. 1b). $P$. tremula and B. pendula displayed the lowest level of drought tolerance, i.e., for these species a noticeable reduction in 
height growth following hot-dry treatment was observed (Fig. 1a). Compared to control, height/diameter ratio was clearly higher in $P$. tremula and $A$. glutinosa under both heat treatments, while in other tree species the treatment effect was rather small (Fig. 1C). Q. robur, however, showed the highest diameter increment following hot-dry treatment (Fig. 1b). In the present study, most severe negative effect of drought was manifested by the dramatic loss of foliage in fast growing tree species $P$. tremula, A. glutinosa and B. pendula (Fig. 1d). Meanwhile, for F. excelsior, Q. robur and conifers the defoliation rate was at the same level or even lower compared to control (Fig. 1d).

Transpiration, stomatal conductance and photosynthetic rates in fast growing deciduous species $P$. tremula, $B$. pendula and $A$. glutinosa were much more affected by water deficit than in other investigated tree species (Fig. 2a, Fig. 2b). These three species showed the highest transpiration rate in ambient conditions and, compared to control, have substantially reduced this rate under hot-dry treatment, while following hot-wet treatment the reduction in transpiration was observed only for $A$. glutinosa and $B$. pendula. In addition to $P$. tremula, noble hardwoods $Q$. robur and $F$. excelsior as well as coniferous species $P$. sylvestris and $P$. abies showed the highest transpiration rates in hot-wet treatment compared to both ambient and hot-dry conditions (Fig. 2a). All investigated tree species except Q. robur has decreased $\mathrm{CO}_{2}$ stomatal conductance following hot-dry treatment, while following hot-wet treatment it increased in all tree species except A. glutinosa and $P$. tremula (data not shown). All species showed a decrease in photosynthetic rate under the hot-dry treatment, with sharpest reduction in $P$. tremula, A. glutinosa and B. pendula (Fig. $2 b$ ). All species except $Q$. robur and $P$. abies showed lower (compared to control) photosynthetic rate in hot-wet treatment (Fig. 2b). As regards WUE, differences among the tested tree species were not large in ambient conditions, although after the hotdry treatment large differences in response among species were observed: $P$. tremula, A. glutinosa and $Q$. robur showed an increase, while $P$. abies, $P$. sylvestris and $B$. pendula showed a clear decrease compared to both control and hot-wet treatments (Fig. 2C). For most species (except $P$. abies), higher pigment concentrations were observed following hot-wet treatment compared to both ambient and hot dry conditions (Fig. 2e-Fig. 2g).

Amounts of MDA and $\mathrm{H}_{2} \mathrm{O}_{2}$ showed significant fluctuations across treatments for different tree species (Fig. 2h, Fig. 2i). Compared to control, the amount of MDA under hot-dry conditions was higher for all tested tree species, and under hot-wet conditions the reactions of most tested tree species were similar: only F. excelsior showed lower MDA amount compared to

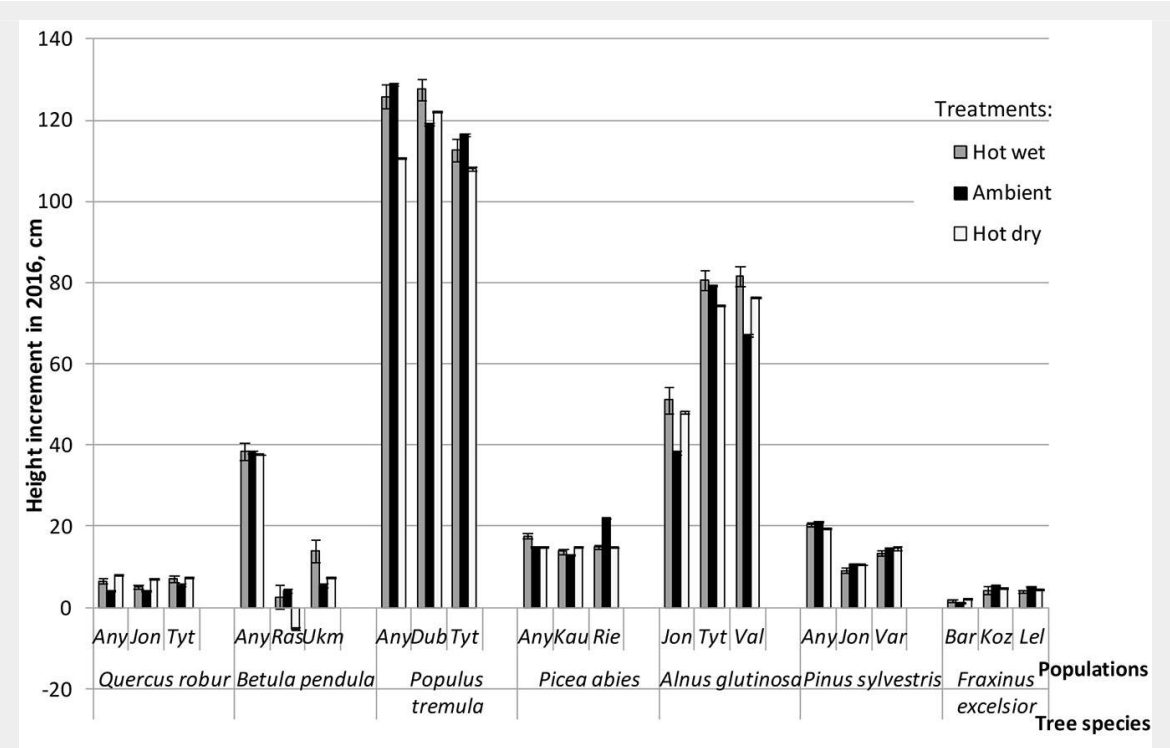

Fig. 3 - Mean tree height increment of populations of seven forest tree species following hot-wet (grey bars), hot-dry (white bars) and control (Ambient - black bars) treatments. Error bars represent the standard error.

ambient conditions (Fig. 2h). For Q. robur, the amount of MDA was significantly higher and the amount of $\mathrm{H}_{2} \mathrm{O}_{2}$ was significantly lower (compared to control) following both heat treatments. For P. sylvestris, a clear (statistically significant) increase in MDA amount (compared to control) was observed following hot-dry treatment, while under hot-wet treatment the increase was negligible. Four tree species ( $A$. glutinosa, $F$. excelsior, $P$. sylvestris and $P$. abies) under hot dry conditions showed higher $\mathrm{H}_{2} \mathrm{O}_{2}$ levels than under both ambient and hot wet conditions (Fig. 2i). Q. robur, B. pendula and $B$. tremula showed the highest amount of $\mathrm{H}_{2} \mathrm{O}_{2}$ in ambient conditions com-

pared to both hot-wet and hot-dry treatments (Fig. 2i).

\section{Population effect}

ANOVA showed that population effect (within tree species) was highly significant $(P<0.001)$ for most traits except for stomatal conductance, transpiration rate, WUE and $W_{U E}$, where significance of the population effect was lower (Tab. 2). Within tree species, significant inter-population differences were observed following each of the three treatments: in height increment for B. pendula and A. glutinosa (Fig. 3), in defoliation rate for $B$. pendula and $P$. tremula (Fig. 4), while for photosynthetic rate the

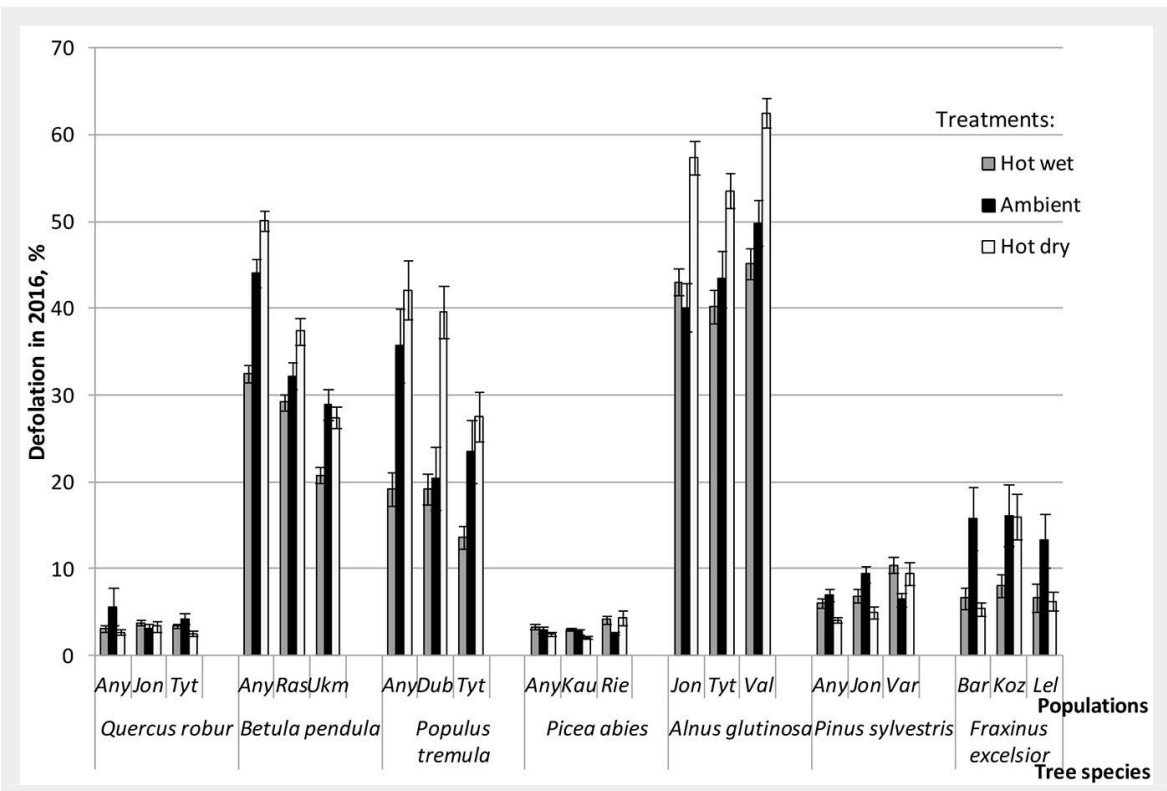

Fig. 4 - Mean defoliation of populations of seven forest tree species following hot-wet (grey bars), hot-dry (white bars) and control (Ambient - black bars) treatments. Error bars represent the standard error. 


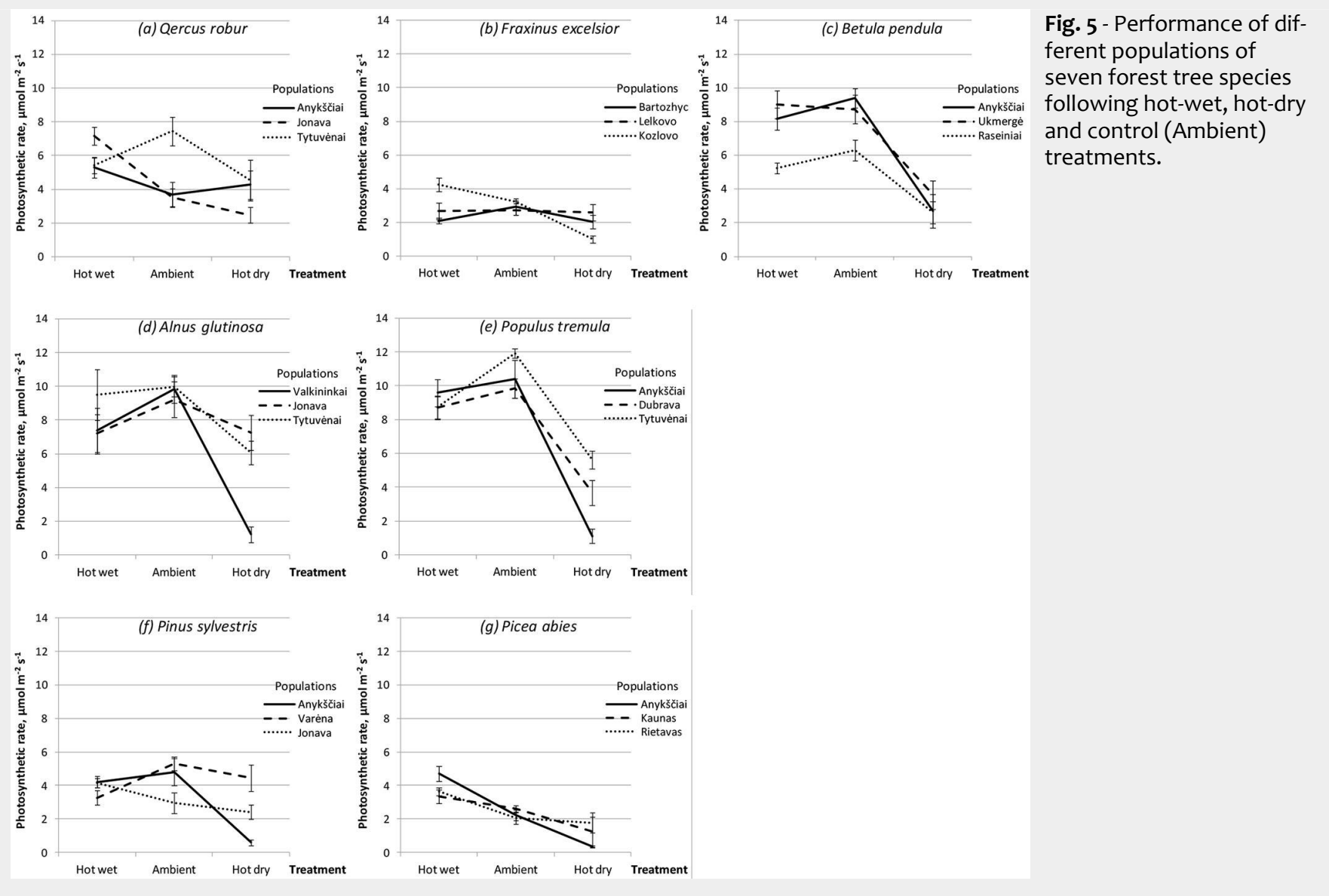

magnitude of these differences varied a lot following all treatments was found for B. species also in diameter increment, reachamong populations depending on treat- pendula and F. excelsior, reaching up to ing up to 51.2 and $39.2 \%$, respectively. Interment (Fig. 5). Very high inter-population 166.2 and 59.5\%, respectively (Tab. 3). High population variation in defoliation rate genetic variation $\left(C V_{p}\right)$ in height increment variation was also found for these two ranged from low to medium for most tree

Tab. 3 - Inter-population genetic variation ( $\mathrm{CVp}$, \%) of morphometric, health condition, physiological and biochemical traits of seven tree species following hot-wet (HW) and hot-dry (HD) treatments and in ambient conditions (control, Amb). For the definition of traits, see Materials and Methods.

\begin{tabular}{|c|c|c|c|c|c|c|c|c|c|c|c|c|c|c|c|c|c|}
\hline \multirow[b]{2}{*}{ Species } & \multirow[b]{2}{*}{ 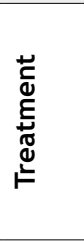 } & \multirow[b]{2}{*}{ 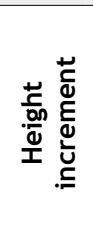 } & \multirow[b]{2}{*}{ 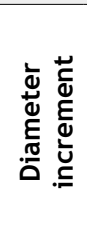 } & \multirow[b]{2}{*}{ 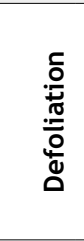 } & \multirow[b]{2}{*}{ 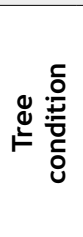 } & \multirow[b]{2}{*}{ 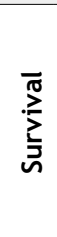 } & \multirow[b]{2}{*}{ 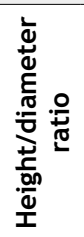 } & \multirow[b]{2}{*}{ 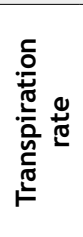 } & \multirow[b]{2}{*}{ 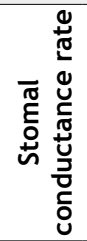 } & \multirow[b]{2}{*}{ 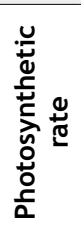 } & \multirow[b]{2}{*}{$\stackrel{山}{3}$} & \multirow[b]{2}{*}{ 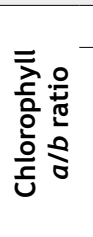 } & \multicolumn{5}{|c|}{ Amount } \\
\hline & & & & & & & & & & & & & $\begin{array}{l}0 \\
\overline{\bar{\lambda}} \\
\text { 음 } \\
\text { 은 } \\
\text { 은 }\end{array}$ & $\begin{array}{l}\stackrel{0}{=} \\
\overline{\bar{\lambda}} \\
\text { 음 } \\
\text { 은 } \\
\text { 은 }\end{array}$ & 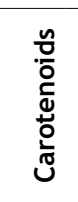 & 方 & ON \\
\hline Pinus & HW & 39.9 & 10.9 & 30.0 & 7.0 & 7.3 & 8.1 & 12.4 & 19.4 & 13.4 & 7.0 & 15.0 & 19.1 & 20.2 & 10.6 & 18.6 & 149.2 \\
\hline \multirow[t]{2}{*}{ sylvestris } & Amb & 34.0 & 11.1 & 20.5 & 3.0 & 3.5 & 3.0 & 16.6 & 12.9 & 28.6 & 14.2 & 6.9 & 13.9 & 18.7 & 16.3 & 5.1 & 35.9 \\
\hline & $\mathrm{HD}$ & 30.3 & 27.3 & 46.2 & 6.3 & 6.6 & 6.3 & 51.4 & 58.7 & 77.1 & 174.2 & 3.2 & 11.5 & 14.2 & 8.8 & 50.2 & 119.9 \\
\hline Picea & $H W$ & 12.8 & 22.6 & 16.8 & 0.5 & 0.9 & 4.3 & 13.5 & 39.0 & 18.2 & 19.6 & 5.4 & 22.9 & 17.3 & 3.2 & 19.6 & 133.4 \\
\hline \multirow[t]{2}{*}{ abies } & Amb & 28.4 & 8.0 & 7.3 & 0.6 & 0.0 & 5.3 & 20.5 & 37.0 & 12.5 & 20.0 & 11.6 & 44.7 & 54.3 & 39.4 & 20.6 & 20.5 \\
\hline & $\mathrm{HD}$ & 0.4 & 23.8 & 41.6 & 1.3 & 1.4 & 4.1 & 37.0 & 96.2 & 63.8 & 81.4 & 7.4 & 18.9 & 13.2 & 9.7 & 10.1 & 28.1 \\
\hline Quercus & HW & 16.8 & 23.0 & 9.5 & 2.7 & 1.2 & 18.3 & 20.3 & 16.6 & 17.4 & 20.9 & 21.8 & 45.2 & 54.1 & 33.7 & 4.6 & 93.4 \\
\hline \multirow{2}{*}{ robur } & Amb & 15.9 & 36.4 & 28.7 & 1.3 & 0.0 & 18.3 & 26.2 & 44.2 & 45.5 & 15.3 & 11.6 & 21.9 & 33.4 & 21.7 & 15.5 & 42.7 \\
\hline & $\mathrm{HD}$ & 5.7 & 14.0 & 15.3 & 0.4 & 1.1 & 15.5 & 4.9 & 3.3 & 30.0 & 34.6 & 22.5 & 48.7 & 59.4 & 33.0 & 6.1 & 21.3 \\
\hline Fraxinus & $H W$ & 42.6 & 15.7 & 11.2 & 8.4 & 2.4 & 3.7 & 32.5 & 37.8 & 36.8 & 13.0 & 5.0 & 13.4 & 9.5 & 20.5 & 28.2 & 36.9 \\
\hline \multirow[t]{2}{*}{ excelsior } & $A m b$ & 59.5 & 39.2 & 10.4 & 2.5 & 0.0 & 9.9 & 9.9 & 6.9 & 8.6 & 16.3 & 8.1 & 22.5 & 26.4 & 11.7 & 23.7 & 37.0 \\
\hline & $\mathrm{HD}$ & 37.8 & 34.8 & 63.9 & 5.7 & 0.7 & 1.6 & 18.4 & 35.8 & 43.0 & 13.8 & 3.6 & 17.6 & 21.0 & 13.8 & 29.2 & 11.0 \\
\hline & $\mathrm{HW}$ & 99.8 & 41.6 & 22.0 & 8.5 & 4.7 & 10.0 & 9.9 & 10.6 & 26.4 & 34.5 & 4.4 & 30.7 & 26.6 & 34.2 & 15.8 & 60.3 \\
\hline \multirow[t]{2}{*}{ pendula } & Amb & 121.2 & 29.2 & 22.6 & 5.5 & 4.8 & 4.2 & 16.8 & 19.0 & 20.0 & 13.8 & 1.4 & 24.8 & 25.8 & 19.1 & 10.7 & 23.8 \\
\hline & HD & 166.2 & 51.2 & 29.6 & 10.7 & 6.5 & 7.5 & 17.4 & 19.4 & 19.2 & 154.5 & 2.9 & 9.6 & 9.0 & 14.4 & 16.3 & 45.5 \\
\hline Alnus & $H W$ & 24.4 & 12.6 & 5.8 & 2.2 & 0.0 & 3.6 & 14.7 & 8.7 & 15.8 & 8.4 & 5.0 & 17.6 & 13.2 & 13.1 & 19.0 & 77.1 \\
\hline \multirow[t]{2}{*}{ glutinosa } & Amb & 34.3 & 6.7 & 11.1 & 5.5 & 1.2 & 1.6 & 10.5 & 19.3 & 4.1 & 8.4 & 1.8 & 12.8 & 14.6 & 12.9 & 3.8 & 17.3 \\
\hline & $\mathrm{HD}$ & 23.7 & 13.7 & 7.8 & 4.7 & 2.3 & 3.6 & 53.6 & 74.3 & 65.7 & 31.2 & 6.1 & 16.2 & 22.6 & 10.3 & 2.5 & 24.9 \\
\hline \multirow{3}{*}{$\begin{array}{l}\text { Populus } \\
\text { tremula }\end{array}$} & HW & 6.7 & 4.7 & 18.4 & 0.6 & 0.0 & 1.6 & 12.5 & 9.3 & 5.6 & 19.0 & 4.8 & 15.8 & 20.0 & 13.0 & 34.9 & 92.0 \\
\hline & Amb & 5.4 & 7.9 & 30.4 & 1.1 & 0.0 & 3.1 & 12.3 & 4.9 & 9.9 & 18.9 & 4.5 & 27.2 & 32.3 & 24.4 & 17.7 & 50.8 \\
\hline & HD & 6.5 & 2.1 & 21.4 & 0.8 & 0.0 & 4.1 & 60.7 & 99.0 & 65.0 & 83.6 & 1.2 & 23.8 & 23.2 & 13.5 & 29.2 & 124.3 \\
\hline
\end{tabular}


Tab. 4 - Phenotypic plasticity and ecovalence in height increment over treatments of different populations of seven tree species following hot-wet (HW), hot-dry (HD) and control (Amb) treatments. For the definition of variables, see Materials and Methods.

\begin{tabular}{|c|c|c|c|c|c|c|c|c|c|c|}
\hline \multirow[t]{2}{*}{ Species } & \multirow[t]{2}{*}{ Population } & \multirow{2}{*}{$\begin{array}{c}\text { Mean } \\
\text { deviation } \\
\text { estimate }\end{array}$} & \multicolumn{3}{|c|}{$\begin{array}{l}\text { Estimates of deviation } \\
\text { from treatment means }\end{array}$} & \multirow{2}{*}{$\begin{array}{l}\text { Phenotypic } \\
\text { plasticity }\end{array}$} & \multirow{2}{*}{$\begin{array}{l}\text { Wricke } \\
\text { ecovalence }\end{array}$} & \multirow{2}{*}{$\begin{array}{c}\text { Shukla } \\
\text { variance }\end{array}$} & \multirow[t]{2}{*}{$F$} & \multirow[t]{2}{*}{$\mathbf{P}$} \\
\hline & & & $\mathrm{HW}$ & Amb & HD & & & & & \\
\hline \multirow{3}{*}{$\begin{array}{l}\text { Pinus } \\
\text { sylvestris }\end{array}$} & Anykščiai & -14 & -14.6 & -13.1 & -14.2 & 1.4 & 0.2 & -0.1 & -0.01 & . \\
\hline & Jonava & -24.2 & -25.5 & -23.5 & -23.6 & 2 & 0.5 & 0.8 & 0.08 & 0.921 \\
\hline & Varena & -20.2 & -21.4 & -19.7 & -19.4 & 2.1 & 0.5 & 0.7 & 0.08 & 0.928 \\
\hline \multirow{3}{*}{$\begin{array}{l}\text { Picea } \\
\text { abies }\end{array}$} & Anykščiai & -18.6 & -17.3 & -19.5 & -19 & 2.3 & 0.6 & 0.9 & 0.14 & 0.868 \\
\hline & Kaunas & -20.4 & -21 & -21.3 & -19 & 2.3 & 0.6 & 1.1 & 0.14 & 0.872 \\
\hline & Rietavas & -17.1 & -19.8 & -12.4 & -19.1 & 7.4 & 6.7 & 17.7 & 2.73 & 0.065 \\
\hline \multirow{3}{*}{$\begin{array}{l}\text { Quercus } \\
\text { robur }\end{array}$} & Anykščiai & -28.1 & -28.1 & -30.1 & -26.2 & 3.8 & 1.5 & 3.4 & 0.39 & 0.677 \\
\hline & Jonava & -28.9 & -29.5 & -30.1 & -27.1 & 3 & 1 & 2.1 & 0.24 & 0.783 \\
\hline & Tytuvenai & -27.7 & -27.6 & -28.8 & -26.8 & 2 & 0.4 & 0.5 & 0.06 & 0.944 \\
\hline \multirow{3}{*}{$\begin{array}{l}\text { Fraxinus } \\
\text { excelsior }\end{array}$} & Bartoszyc & -32.7 & -32.8 & -33 & -32.2 & 0.8 & 0.1 & -0.5 & -0.05 & . \\
\hline & Kozlowo & -29.6 & -30.3 & -28.9 & -29.5 & 1.4 & 0.2 & -0.1 & -0.01 & . \\
\hline & Lelkowo & -29.8 & -30.5 & -29.2 & -29.8 & 1.3 & 0.2 & -0.2 & -0.02 & . \\
\hline \multirow{3}{*}{$\begin{array}{l}\text { Betula } \\
\text { pendula }\end{array}$} & Anykščiai & 3.8 & 3 & 3.8 & 4.7 & 1.7 & 0.3 & 0.1 & 0.02 & 0.981 \\
\hline & Raseiniai & -34 & -31.8 & -30.1 & -39.9 & 9.8 & 11.1 & 29.8 & 3.37 & 0.034 \\
\hline & Ukmerge & -25.5 & -20.9 & -28.9 & -26.8 & 8 & 6.9 & 18.3 & 2.33 & 0.098 \\
\hline \multirow{3}{*}{$\begin{array}{l}\text { Alnus } \\
\text { glutinosa }\end{array}$} & Jonava & 11.5 & 15.2 & 3.7 & 15.5 & 11.9 & 18.3 & 49.6 & 5.68 & 0.003 \\
\hline & Tytuvenai & 43.7 & 43.9 & 44.5 & 42.8 & 1.6 & 0.3 & 0.1 & 0.01 & 0.986 \\
\hline & Valkininkai & 40.7 & 44.9 & 32.3 & 44.9 & 12.7 & 21.4 & 58.1 & 6.77 & 0.001 \\
\hline \multirow{3}{*}{$\begin{array}{l}\text { Populus } \\
\text { tremula }\end{array}$} & Anykščiai & 87.4 & 87.7 & 93.8 & 80.6 & 13.3 & 17.7 & 48 & 5.6 & 0.004 \\
\hline & Dubrava & 88.6 & 89.4 & 84 & 92.5 & 8.5 & 7.4 & 19.8 & 2.32 & 0.099 \\
\hline & Tytuvenai & 78.1 & 74.9 & 81.4 & 77.9 & 6.5 & 4.3 & 11 & 1.29 & 0.277 \\
\hline
\end{tabular}

species, although following hot dry treatment the variation was rather substantial for $F$. excelsior, $P$. sylvestris and $P$. abies, reaching up to $63.9,46.2$ and $41.6 \%$, respectively (Tab. 3).

Inter-population genetic variation in transpiration, stomatal conduction and photosynthetic rates varied a lot depending on treatment (Tab. 3). Clearly the highest inter-population variation in these traits was observed for $P$. sylvestris, $P$. abies, A. glutinosa and $P$. tremula under the hot-dry treatment, for $F$. excelsior in the hot-wet treatment (in transpiration and stomatal conduction rates only), and for $Q$. robur at ambient conditions (Tab. 3). In the most stressful hot-dry treatment, inter-population genetic variation in WUE was significantly larger compared to both hot-wet treatment and control for all tree species except $F$. excelsior (Tab. 3). Extremely large inter-population variation in WUE was found for P. sylvestris, B. pendula, P. tremula and $P$. abies. The highest inter-population variation in amount of chlorophylls $a$ and $b$ and their ratio was observed for $Q$. robur and $A$. glutinosa following hot-dry treatment, for $P$. sylvestris and B. pendula following hot-wet treatment, and for $P$. abies, F. excelsior and P. tremula at ambient conditions. Similar variation patterns among the tested tree species were observed in the concentration of carotenoids (Tab. 3).

As regards the amount of MDA, the highest inter-population variation was observed for $P$. sylvestris, $F$. excelsior and $B$. pendula under the hot-dry treatment, for A. glutinosa and P. tremula following hotwet treatment, and for $P$. abies and $Q$. robur in ambient conditions (Tab. 3). Very high variation in the amount of $\mathrm{H}_{2} \mathrm{O}_{2}$ was found for $P$. sylvestris and $P$. tremula following the hot-dry treatment, meanwhile in the hot-wet treatment the variation was very high for $P$. sylvestris, $P$. abies, $Q$. robur and $P$. tremula. In ambient conditions (control), the variation in the amount of $\mathrm{H}_{2} \mathrm{O}_{2}$ was the lowest across treatments for most of the tested species (Tab. 3).

\section{Population-by-treatment interaction}

Significant $(P<0.05)$ population-by-treatment interaction (hereafter referred to as $\mathrm{G}_{\mathrm{p}} \times \mathrm{E}$ interaction) was found for most morphometric, health condition, physiological and biochemical traits except tree condition and survival rates (Tab. 2).

In general, the contribution of individual

populations to the $G_{p} \times E$ interaction in height growth was not high, and only four out of 21 studied populations showed high plasticity and have contributed significantly to the interaction with ecovalences ranging between 11.1 and 21.4\% (Tab. 4). This interaction was due to both reduction and increase of height increment in most sensitive/reactive populations of $B$. pendula, $P$. tremula and $A$. glutinosa across treatments (Fig. 3, Tab. 4). These species also showed the largest variation in defoliation rates among the three investigated populations across all treatments compared to other tested species (Fig. 4). Largest rank changes among populations in defoliation following different treatments were observed for $P$. tremula and A. glutinosa (Fig.

Tab. 5 - Results of Principal Factor Analysis of a complex of morphometric, health condition, physiological and biochemical traits in seven investigated tree species and their populations: factor structure - semipartial correlations. (a): For trait definitions see Materials and Methods. The strongest correlations are indicated (b).

\begin{tabular}{lccc}
\hline \multirow{2}{*}{ Trait $^{\text {(a) }}$} & \multicolumn{3}{c}{ Semipartial Correlations } \\
\cline { 2 - 4 } & Factor1 & Factor2 & Factor3 \\
\hline Height increment & 0.308 & $0.538^{\mathrm{b}}$ & 0.050 \\
Diameter increment & $0.191^{\mathrm{b}}$ & $0.521^{\mathrm{b}}$ & 0.123 \\
Height/diameter ratio & $0.602^{\mathrm{b}}$ & 0.150 & 0.091 \\
Defoliation & $0.588^{\mathrm{b}}$ & -0.023 & -0.084 \\
Health condition & $-0.118^{\mathrm{b}}$ & 0.180 & -0.023 \\
Transpiration rate & $0.483^{\mathrm{b}}$ & 0.074 & 0.290 \\
Photosynthetic rate & $0.482^{\mathrm{b}}$ & 0.015 & $0.427^{\mathrm{b}}$ \\
Carotenoids & $0.916^{\mathrm{b}}$ & -0.167 & $-0.062^{\mathrm{b}}$ \\
$\mathrm{MDA}$ & $-0.121^{\mathrm{b}}$ & $-0.469^{\mathrm{b}}$ & -0.009 \\
$\mathrm{H}_{2} \mathrm{O}_{2}$ & 0.158 & $-0.618^{\mathrm{b}}$ & $0.346^{\mathrm{b}}$ \\
Chlorophyll $b$ & $0.879^{\mathrm{b}}$ & -0.049 & -0.109 \\
Chlorophyll $a$ & $0.845^{\mathrm{b}}$ & -0.001 & -0.260 \\
Chlorophyll $a / b$ ratio & -0.211 & -0.124 & $0.648^{\mathrm{b}}$ \\
\hline
\end{tabular}




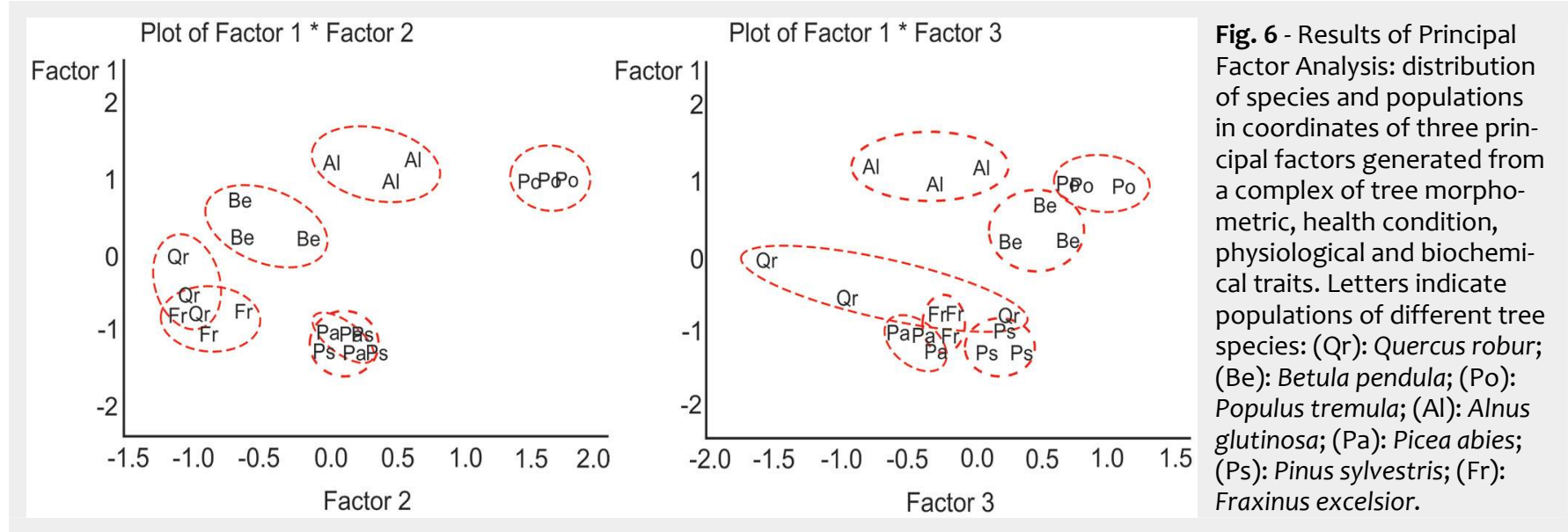

). Defoliation rate in three populations of B. pendula was very different, the Anykščiai population had highest defoliation rate in all treatments, however no rank changes were observed following different treatments (Fig. 4).

The most significant $G_{p} \times E$ interaction was found for concentrations of chlorophylls $a$ and $b$ and carotenoids, and for the amounts of MDA and $\mathrm{H}_{2} \mathrm{O}_{2}$ (Tab. 2). All populations of all investigated tree species showed different response to treatments in photosynthetic rate (Fig. 5). For example, in ambient conditions Q. robur from the Tytuvenai population showed a photosynthetic rate higher by $51 \%$ as compared to that recorded for the other two populations (Fig. 5a). Compared to control, the photosynthetic rate of oak from Tytuvenai population was by $40 \%$ lower in the hotwet and by $30 \%$ lower in the hot-dry treatments. Saplings from Anykščiai and Jonava populations showed the highest photosynthetic rates following hot-wet treatment Under the hot-dry treatment, the photosynthetic rate of Jonava population has decreased by $30 \%$, while in Anykščiai population it increased by $16 \%$ and reached the same rate as the Tytuvenai population (Fig. 5a).

Principal Factor Analysis of the multiple characteristics of species and populations across treatments has revealed three main factors (Tab. 5). The factor structure indicates that Factor 1 with the highest positive semipartial coefficients of correlation accounted for the variation in concentration of carotenoids, chlorophylls $a$ and $b$, $\mathrm{H} / \mathrm{D}$ ratio, defoliation, transpiration and photosynthetic rates (Tab. 5). Factor 2 showed a strong positive correlation with tree height and diameter increments, while negatively correlated with the amounts of MDA and $\mathrm{H}_{2} \mathrm{O}_{2}$. Factor 3 strongly positively correlated with chlorophyll $\mathrm{a} / \mathrm{b}$ ratio, photosynthetic rate and amount of $\mathrm{H}_{2} \mathrm{O}_{2}$. Fig. 6 shows that populations of three deciduous tree species $P$. tremula, A. glutinosa and B. pendula were clearly separated from each other and from the rest of the species studied. These three species had the highest values of Factor 1. Populations of $P$. tremula had the highest values of all three factors. Populations of $P$. abies and $P$. sylvestris had the lowest values of Factor 1 and overlapped in coordinates of Factors 1 and 2 with a small separation in Factor 3 . Populations of Q. robur and F. excelsior had the lowest values of Factors 1 and 2 and partially overlapped (Fig. 6).

\section{Discussion}

In this study significant inter-species effects and species-by-treatment interaction for almost all tree morphometric, health condition, physiological and biochemical traits show that tree responses to the applied treatments are species-specific. The investigated tree species showed different sensitivity to stressful conditions, exhibiting different physiological reactions and growth performance which can be considered as specific acclimation strategies to cope with stress. This suggests that effects of different treatments should not be generalized and have to be analyzed for each species separately. At the same time, tree reaction to treatments is expressed differently in different tree traits as they do not have the same acclimative/adaptive value. Tree height increment is regarded to be the most important trait in competition for light at juvenile age. The present study showed that elevated temperatures neither at wet nor at simulated drought conditions had significant positive effect on sapling height increment, except A. glutinosa, and Q. robur (Fig. 1a). Stress-induced differences (as compared to control) were more pronounced in stem diameter increment (mostly having a negative effect, in particular for A. glutinosa and P. tremula) than in height increment. This suggests that increment losses in stem diameter due to drought are compensated via internal relocation of biomass to height growth to sustain the competitive ability of trees affected by stress. The unequal treatment effect observed in this study is in agreement with earlier findings by Matyssek et al. (1992), who showed that the reduction of increment under stress condition is more pronounced for diameter than for height. The increase of height to diameter ratio under both hot-wet and hot-dry conditions compared to control might also be related to stress-induced acceleration of growth as reaction to lower light intensity in phytotron than in ambient conditions.

Limited water availability during vegetation season can cause premature tree leaf shedding and lead to growth reduction. Tree species that had the highest transpiration rate in ambient conditions (A. glutinosa, $B$. pendula and $P$. tremula) demonstrated a specific combined strategy to cope with drought: in the hot-dry treatment they have closed stomata to reduce stomatal conductance and transpiration, which has negatively affected photosynthesis rate, and also have shed a portion of leaves. Interestingly, B. pendula and A. glutinosa, compared to control showed lower transpiration rate also in the hot-wet treatment, while $P$. tremula showed the opposite reaction (Fig. 2a). It should be noted that in control treatment, $F$. excelsior showed the highest defoliation among all treatments most likely because of damages by an ash dieback pathogen $\mathrm{Hy}$ menoscyphus fraxineus (T. Kowalski) Baral, Queloz \& Hosoya, whose infection rate was higher outdoors than in the phytotron. Larger WUE values observed in $P$. tremula, Q. robur and A. glutinosa under the hotdry treatment (as compared to control) gives an indication that these species are more efficient responders to heat and drought stress as they are able to maintain a balance between photosynthesis and transpiration. Our observations are consistent with the results of previous studies on reactions of various plant species tested under hot and dry growth conditions (Gratani et al. 2000, Guo et al. 2006, Wikberg \& Ogren 2007, Medrano et al. 2015). It has been demonstrated that drought causes a significant increase, while high temperature causes a significant decrease, in the intrinsic water use efficiency $\left(W E_{i}, A / g_{s}\right)$ for several forest tree species, e.g., Populus spp. (Zhang et al. 2004, Yin et al. 2005, Monclus et al. 2006), Quercus ilex L. (Gratani et al. 2000) and B. pendula (Kellomäki \& Wang 2001). The increase in $\mathrm{WUE}_{\mathrm{i}}$ is mainly due to a decrease in the stomatal conductance caused by drought (Zhang et al. 2005), while the decrease in WUE results from an increase in the transpiration 
rate due to high temperature (Kellomäki \& Wang 2001). Significantly lower WUE values (compared to control) found during the present study for P. abies, P. sylvestris and $B$. pendula in the hot-dry treatment are in agreement with the results obtained in studies on poplars, almonds and Mediterranean shrubs, where a clear decrease of instantaneous WUE under water deficit has been demonstrated (Klein et al. 2001, Llorens et al. 2003, Liang et al. 2006). Interestingly, in the present study a poplar species $P$. tremula showed the opposite reaction: higher WUE values were found following hot-dry treatment. It has been demonstrated that even closely related poplar species react to drought differently (Pallardy \& Kozlowski 1981, Strong \& Hansen 1991, Tschaplinski et al. 1994). Pattern of WUE changes might be related to environments of species' or populations' origin. For example, studies on Castanea sativa Mill. populations from contrasting xeric and mesic habitats showed that droughtadapted Mediterranean ecotype exhibited lower WUE values than the eastern wetadapted one (Lauteri et al. 1997b, 2004).

Our study confirmed the results obtained by Griffin et al. (2004) who showed that elevated temperature (up to $40^{\circ} \mathrm{C}$ ) increased the carbon fixation in two ecotypes of redbud (Cercis canadensis L.), and that watered plants had significantly greater carbon fixation rates than plants grown under water deficit stress. In our study, photosynthetic rate and pigment concentrations were in most cases much greater in hotwet than in hot-dry treatment, indicating that water deficit inhibits photosynthetic processes and reduces positive effect of the temperature increase. Similarly, reduction of net photosynthesis rate caused by drought was found in numerous studies ( $\mathrm{Li}$ et al. 2004, Reddy et al. 2004, Yin et al. 2005, Ma et al. 2014). Stomata closure and photoinhibitory damage are considered as the major factors responsible for the depression of assimilation rate (Muraoka et al. 2000). Xu et al. (2008) demonstrated that drought treatment of Populus cathayana Rehd. juveniles (cuttings) had significant negative effect on their growth and net photosynthesis rate, and increased WUE $_{\mathrm{i}}$ and malondialdehyde (MDA) content. In contrast, elevated temperatures and good water supply significantly accelerated $P$. cathayana growth and net photosynthesis rate, but decreased $W_{U} E_{i}$, and MDA content.

Stomatal limitations largely account for a reduction of $\mathrm{CO}_{2}$ assimilation under mild to moderate drought stress, whereas nonstomatal limitations may become dominant under severe drought (Tezara \& Lawlor 1995, Flexas et al. 2004, Flexas et al. 2006, Ma et al. 2014). Although in field studies trees of genus Quercus often display high photosynthetic capacity and stomatal conductance, the stomatal control of gas exchange in response to water availability is more common than in other co-oc- curring tree species (Bahari et al. 1985, Ni \& Pallardy 1991). In our study, Q. robur has increased $\mathrm{CO}_{2}$ stomatal conductance following hot-dry treatment (while in all other tree species it decreased) and this may helped to avoid such severe loss of photosynthetic rate observed in other tree species. It has been shown that stomatal control of gas exchange may act as an important physiological mechanism influencing distribution of Quercus rubra L., Q. pirinus L. and Acer rubrum L. (Turnbull et al. 2002). In a study by Ni \& Pallardy (1991), more xeric species showed higher photosynthetic rate and increased leaf water vapor conductance under both well-watered and water-deficient conditions. However, a trend towards increased WUE in more xeric species has not been observed either in the above-mentioned ( $\mathrm{Ni} \&$ Pallardy 1991) nor in our study for $P$. sylvestris.

Results of the present study suggest that the production of most important plant pigments is enhanced under hot and wet conditions, while arid conditions have a more negative impact on pigment production. This, however, does not hold true for all tested species. For example, for P. sylvestris both treatments had positive effect (compared to control) on production of all the analysed pigments, while for $P$. abies the effect was always negative or neutral. Decline in carotenoid concentration following drought stress and high $\mathrm{CO}_{2}$ concentrations was observed by Schwanz \& Polle (2001) in Q. robur and Pinus pinaster Ait. Higher $\mathrm{H}_{2} \mathrm{O}_{2}$ levels (compared to control) recorded following drought stress in $A$. glutinosa, $F$. excelsior, $P$. sylvestris and $P$. abies suggest that these four tree species at young age are sensitive to water deficit. The greater increase of MDA concentration following the hot-dry treatment also indicates that oxidative damage is taking place in membranes of all tested tree species. Maintenance of membrane stability is critical for plant survival under environmental stress (Wahid et al. 2007). In the present study, combined stressful conditions, drought and heat, caused significantly stronger oxidative stress in tree leaves compared to that recorded in the hot-wet treatment. These results are consistent with the findings of similar studies on responses of olive trees (Sofo et al. 2004, Bacelar et al. 2007) and cowpea (Souza et al. 2004). $\mathrm{H}_{2} \mathrm{O}_{2}$ plays dual role in plants; as a signaling molecule it is involved in the regulation of various environmental stresses at optimal level between 0.1 and $5 \mu \mathrm{mol} \mathrm{g}^{-1}$ FW, while high concentrations are capable to induce cellular damage (Veljovic-Jovanovic et al. 2002, Cheeseman 2007). In the present study, F. excelsior, B. pendula and Q. robur had much higher $\mathrm{H}_{2} \mathrm{O}_{2}$ levels than optimal, thus indicating tree response to stress and causing cell oxidative damage, which is partially responsible for plant growth inhibition.

It is argued that certain external stressors may reduce plant tolerance to secondary stressors, i.e., when internal reserves of an organism are being depleted for coping with the primary stressors it gets more vulnerable (Pianka 1978, Duchovskis et al. 2002). On the other hand, if plant adaptive mechanisms are built to cope with different kinds of stress, such a plant, being adapted to one stressor, may be more tolerant to another one (Cox \& Hutchinson 1980, Larcher 1995, Pliura et al. 2008). The observed significant treatment effects indicate generally high phenotypic plasticity of all tree species tested in the present study. Our results suggest that in a short term trees (at least at juvenile age) are able to respond to stressors, although plastic response and possibilities for acclimation and adaptation of different tree species may vary considerably. Large phenotypic plasticity in adaptive traits may be useful under changing conditions in a short-time perspective, but may be detrimental in a long term since it may not allow natural selection to act in full power (Eriksson 2001).

The highly-significant population effect found in our study for most traits - except stomatal conductance, transpiration rate, WUE and $W_{U} E_{i}$ - shows that populations of certain species differ in their adaptive response. The absence or presence of a weak population effect in these four traits may be explained by differing reaction of different populations to treatments, which is indicated by a highly significant populationby-treatment interaction effect. Very high inter-population genetic variation in height and diameter increments found for $B$. pendula and $F$. excelsior shows that populations of these species are the most different among all populations tested, which can be due to existing adaptations to specific site conditions in the place of their origin. Jensen \& Hansen (2010) also found a significant population effect in tree height, stem diameter, shoot and root biomass in their study of $22 \mathrm{Q}$. robur populations from Central and Northern Europe in a greenhouse irrigation experiment.

Survival of plant populations and even of separate species will depend on abilities to acclimate and to adapt to relatively rapidly changing environmental conditions both physiologically and genetically. Genetic adaptability is determined by genetic variation of adaptive traits within and among populations, by ecogenetic plasticity, genotype by environment interaction, inter- and intra-population structure, population size and other factors (Eriksson 1998, 2001). Tree species differ from each other by a complex of biological and ecological traits such as successional stage in the ecosystem, character of self- and cross-pollination and seed dispersal, tree social status, distribution patterns in the natural range, size and structure of populations, particularities of post-glacial migration, etc. (Hamrick \& Godt 1989). All these traits affect genetic variation also at intra-population levels, which in turn determines the possibility of natural selection and adaptation. Large dis- 
tribution ranges of most deciduous tree species and high diversity of environmental conditions within these ranges precondition the climatic and edaphic differentiation of populations in the course of species' evolution. Wide distribution range in connection with occurrence of small isolated populations of a certain species determines large intra-specific genetic variation (Weisgerber 1974). Widely distributed social tree species are characterized by high inter-population variability, whereas their intra-population variability is smaller. Species-specific combinations of bioecological traits affect species' genetic interpopulation diversity in different directions. Logically, such tree species as $P$. sylvestris, $P$. abies, B. pendula and P. tremula should be characterized by high inter-population variability, while $Q$. robur and $F$. excelsior by lower variability. No such trend, however, was observed in the present study, the inter-population variability varied a lot among species depending on treatments and traits studied (Tab. 3 ).

Results of Principal Factor Analysis (PFA) on the complex of studied traits allowed to discriminate and/or to group tree species and populations according to their ecological reaction across treatments. Clear separation of three deciduous species $P$. tremula, A. glutinosa and B. pendula from each other and from the rest of the tested species in plots of principal factors of PFA indicates largely different ecological behavior of those three species. In Europe, A. glutinosa is considered an asocial tree species with scattered distribution. In Lithuania, this species has a wide distribution and demonstrates a social character by forming forest stands. Our study confirms these ecological features of A. glutinosa; indeed, in the factor diagram populations of this species are located closer to P. tremula than to $Q$. robur and F. excelsior. Populations of $P$. abies and $P$. sylvestris may be considered as exhibiting a generally similar reaction to treatments, as suggested by their partial overlap in PFA plots (Factor $1 \times$ Factor 2 - Fig. 6). Populations of Q. robur and $F$. excelsior formed a distinct group (Fig. 6), thus confirming their similar ecological behavior.

Significant population-by-treatment interaction found in the present study for most morphometric, health condition (except tree condition and survival), physiological and biochemical traits shows different response and plasticity of tree populations to the applied treatments and indicates a presence of specific site-related or climaterelated adaptations. The absence of interaction between tree conditions and survival may be explained by a delay in the occurrence of visible tree damages and/or mortality, when treatment impact on morphometric, photosynthesis rate and other physiological and biochemical traits was already evident and scorable. Responses of the tested populations varied depending on different combinations of temperature and water regimes. Skre (1991) investigated the response of progenies from geographically distant populations of B. pendula and B. pubescens under different temperature (and photoperiod) treatments in climatic chambers. Some of the investigated populations showed good growth at extreme temperatures, while other populations at moderate temperatures; differences among populations in net assimilation rate were found to be smaller at lower temperatures (Skre 1991), which is in agreement with our findings. In a study of 22 Q. robur populations from Central and Northern Europe in a greenhouse irrigation experiment, population $\times$ watering interaction effect was significant and more pronounced than population effect for stem diameter, similarly pronounced for tree height and number of lamma shoots, and less pronounced for shoot biomass and shoot/root ratio, while no interaction was found for root biomass and growth cessation (Jensen \& Hansen 2010). In Turkey, two physiological types of Castanea sativa Mill. populations, drought-adapted and wet-adapted, were identified (Lauteri et al. 1999, Villani et al. 1999). WUE has been found to be a reliable indicator of complex adaptive mechanisms that differentiate wet- and drought-adapted populations (Lauteri et al. 1997b, 1999, 2004). At juvenile stage, a slower increment of above-ground biomass was found for drought-adapted Mediterranean C. sativa genotypes compared to eastern wet-adapted genotypes, while at maturity growth patterns have changed in the opposite way (Villani et al. 1992, Lauteri et al. 1997a).

In our previous study (Pliura et al. 2016), a significant genotype by environment $(\mathrm{C} \times$ E) interaction for tree survival was found in F. excelsior juveniles tested under simulated summer drought and spring frost conditions, indicating that condition of different genotypes unequally depends on environmental conditions. Ecophysiological studies highlighted different mechanisms of response to water stress depending on site conditions at the origin location (Lauteri et al. 1997a, 1997b, 2004). Lauteri et al. (1999) reported a higher capacity of photosynthesis and transpiration in C. sativa seedlings from populations from arid sites than in those from mesic sites. Studies of genetic variation in these traits in material from the whole distribution range of $C$. sativa indicated inter- and intra-population genetic variation in drought tolerance (Pliura \& Eriksson 2002, Lauteri et al. 2004). High phenotypic plasticity, which is an outcome of poor performance of certain genotypes, can aid natural selection by eliminating the least adaptive genotypes or populations thus enhancing general population/species adaptedness. This somehow contradicts a conclusion by Ghalambor et al. (2007), who claimed that only plasticity that enhances fitness can facilitate adaptive evolution of a species. Genetically depleted populations are less likely to cope with environmental stress under changing environmental conditions and may be more prone to inbreeding depression, with loss of productive performance (Ellstrand 1992).

Deciduous forest-forming tree species have immigrated to the current territory of Lithuania after the last glacial period (6-9 thous. years ago) from refugee populations in Balkans, Apennines and other areas of southern Europe (Csaikl et al. 2002). The offspring from these southern populations had too short time to adapt to rapidly changing environmental conditions in north-temperate regions because of long tree ontogenesis and prolonged period of generational change. Adaptation of forest trees has also been encumbered by frequent shifts and fluctuations of climatic and local environmental conditions during tree ontogenesis and through the ages, by high phenogenetic plasticity of trees and other factors. It can be speculated that ancient Lithuanian populations of deciduous forest-forming tree species have conserved part of their former environment-specific adaptation to southern drought-prone refugia, as well as the plasticity and specific reactions to environmental fluctuations; however, their current adaptive significance is unclear. If growth, morphological and physiological reactions of species and populations observed in the present study are not acclimative/adaptive, the negative consequences of this may get expressed in the next future via reduced growth, declining health conditions and decreasing survival rate. Therefore, further studies on how the induced physiological responses will be carried over into the following years and how they will affect growth and development of the treated trees are needed.

\section{Conclusions}

Our results showed a great response variability (as expressed by different morphometric, health condition, physiological and biochemical traits) among tested tree species and their populations exposed to climate change-related stressors at juvenile age. Under the hot-dry treatment, most deciduous species showed smaller height and diameter increment, lower transpiration and photosynthetic rates and higher defoliation rates compared to ambient conditions, meanwhile different reactions of different tree species, both negative and positive (compared to control), were observed under the hot-wet treatment. However, for conifers and $Q$. robur, the effect of treatment on these traits was negligible. Photosynthetic and transpiration rates were the highest in the fast-growing species $P$. tremula, B. pendula and A. glutinosa, however these rates were much more negatively affected by water deficit than in other tree species. These three species demonstrated a specific combined acclimation strategy to cope with drought stress, including stomata closure to reduce stomal conductance and transpiration rate, and (partial) leaf 
shedding.

Lower photosynthetic rate observed under hot-wet treatment in all tested species (except Q. robur and P. abies) indicates that heat waves can negatively affect the physiology of certain tree species, even at good availability of water. Moreover, the large amount of MDA observed for most species under the hot-dry treatment suggest a stronger oxidative stress compared to hotwet and ambient conditions. Production of chlorophylls $a$ and $b$ and carotenoids is likely positively affected by elevated temperatures and water availability, while hotdry conditions are likely to cause some negative effect on pigment production, though quite a few exceptions were observed.

Significant population effect and population-by-treatment interaction for most traits indicate different plasticity and response of each population to stressful conditions. However, only a small fraction of populations showed high plasticity/ecovalence and significantly contributed to the population-by-treatment interaction. Specific reactions of such populations may be related to a presence of specific site- or climate-related pre-adaptations.

Some of the observed responses of species and populations to hot-dry treatment resulted in lower performances and a decrease in tree growth, and theferore cannot be considered as adaptive acclimation. Different physiological responses of populations/species at juvenile stages could unbalance the competition among species, particularly following heat waves and drought. This may compromise forest regeneration, cause atypical species successions and reduce the sustainability of future forest ecosystems. Specific shortterm reactions/acclimation performances observed in this study represent a solid incentive for further investigations on the adaptive potential of forest trees.

\section{Acknowledgements}

The study was carried out under the $\mathrm{Na}$ tional Research Program project SIT-4/2015 'MISKOEKOKAITA' that was funded by the Research Council of Lithuania. We are grateful to staff of the phytotron for technical assistance in running the experiments and performing measurements. We are grateful to anonymous reviewers for their constructive comments and advices.

\section{References}

Allen CD, Macalady AK, Chenchouni H, Bachelet $D$, Mcdowell $N$, Vennetier $M$, Kitzberger $T$, Rigling A, Breshears DD, Hogg E, Gonzalez P, Fensham R, Zhang Z, Castro J, Demidova N, Lim $\mathrm{JH}$, Allard G, Running SW, Semerci A, Cobb N (2010). A global overview of drought and heatinduced tree mortality reveals emerging climate change risks for forests. Forest Ecology and Management 259 (4): 660-684. - doi: 10.1016/j.foreco.2009.09.001

Anonymous (2017). Climate indices. Lithuanian Hydrometeorological Service, Ministry of Envi- ronment, Lithuania. [online] URL: http://www. meteo.It/en/climate-indices

Apel K, Hirt H (2004). Reactive oxygen species: metabolism, oxidative stress, and signal transduction. Annual Review of Plant Biology 55: 373-39. - doi: 10.1146/annurev.arplant.55.031903 .141701

Bacelar EA, Santos DL, Moutinho-Pereira JM, Lopes JI, Goncalves BC, Ferreira T, Correia CM (2007). Physiological behaviour, oxidative damage and antioxidative protection of olive trees grown under different irrigation regimes. Plant Soil 292: 1-12. - doi: 10.1007/s11104-006-9088-1 Bachelet D, Neilson RP, Lenihan JM, Drapek RJ (2001). Climate change effects on vegetation distribution and carbon budget in the United States. Ecosystems 4 (3): 164-185. - doi: 10.1007/ S10021-001-0002-7

Bahari ZA, Pallardy SC, Parker WC (1985). Photosynthesis, water relations, and drought adaptation in six woody species of oak-hickory forests in central Missouri. Forest Science 31 (3): 557569. [online] URL: http://academic.oup.com/ forestscience/article-abstract/31/3/557/4656987 Baliuckas V (2002). Life history traits and broadleaved tree genetics. PhD thesis. Acta Universitatis Agriculturae Sueciae. Silvestria 258. Swedish University of Agricultural Sciences, Uppsala, Sweden, pp. 118.

Baliuckas V, Pliura A (2003). Genetic variation and phenotypic plasticity of Quercus robur populations and open pollinated families in Lithuania. Scandinavian Journal of Forest Research 18 (4):305-319. - doi: 10.1080/02827580310005153 Belkadhi A, De Haro A, Soengas P, Obregon S, Cartea ME, Chaibi W, Djebali W (2014). Salicylic acid increases tolerance to oxidative stress induced by hydrogen peroxide accumulation in leaves of cadmium-exposed flax (Linum usitatissimum L.). Journal of Plant Interactions 9 (1): 647-654. - doi: 10.1080/17429145.2014.890 751

Bhargava S, Sawant K (2013). Drought stress adaptation: metabolic adjustment and regulation of gene expression. Plant Breeding 132 (1): 21-32. - doi: 10.1111/pbr.12004

Chakraborty S, Tiedemann AV, Teng PS (2000). Climate change: potential impact on plant diseases. Environmental Pollution 108: 317-326. doi: 10.1016/S0269-7491(99)00210-9

Cheeseman JM (2007). Hydrogen peroxide and plants stress: a challenging relationship. Plant Stress 1 (1): 4-15.

Chromov SP (1968). Meteorológia a klimatológia [Meteorology and climatology]. Vydavatel'stvo Slovenskej Academievied, Bratislava, Slovakia. [in Slovak]

Clapham DH, Ekberg I, Dormling I, Eriksson G, Qamaruddin M, Vince-Prue D (1998). Dormancy: night timekeeping and day timekeeping for the photoperiodic control of budset in Norway spruce. In: "Biological Rhythms and Photoperiodism in Plants" (Lumsden PJ, Millar AJ eds). BIOS Scientific Publishers Ltd, Oxford, UK, pp. 195-209.

Cox RM, Hutchinson TC (1980). Multiple-metal tolerances in the grass Deschampsia cespitosa from the Sudbury smelting area. New Phytologist 84: 631-647. - doi: 10.1111/j.1469-8137.1980. tb04777.x

CsaikI UM, Glaz I, Baliuckas V, Petit RJ, Jensen JS
(2002). Chloroplast DNA variation of white oak in the Baltic countries and Poland. Forest Ecology and Management 156 (1-3): 211-222. - doi: 10.1016/S0378-1127(01)00644-2

Dalle-Donne I, Rossi R, Giustarini D, Milzani A, Colombo R (2003). Protein carbonyl groups as biomarkers of oxidative stress. Clinica Chimica Acta 329: 23-28. - doi: 10.1016/Sooog-8981(03) 00003-2

Davison PA, Hunter CN, Horton P (2002). Overexpression of beta-carotene hydroxylase enhances stress tolerance in Arabidopsis. Nature 418: 203-206. - doi: 10.1038/natureo0861

Dormling I, Gustafsson A, Wettstein DV (1968). The experimental control of the life cycle in Picea abies (L.) Karst. Silvae Genetica 17 (23): 44-64.

Duchovskis P, Brazaityte A, Juknys R, Zukauskaite I, Sliesaravičius A (2002). Kompleksinis antropogeniniu veiksniu poveikis pigmentu kiekiui pomidoru lapuose [The impact of cadmium on pigments accumulation in tomato leaves at background of different amount of the biogenic materials and substratum acidity]. Sodininkyste ir Daržininkyste 21 (4): 111-118. [in Lithuanian]

EEA (2002). Europe's biodiversity - biogeographical regions and seas. EEA Report No 1/2002, European Environment Agency, Copenhagen, Denmark. [online] URL: http://www.eea.euro pa.eu/publications/report_2002_0524_154909 Ellstrand NC (1992). Gene flow by pollen: implications for plant conservation genetics. Oikos 63 (1): 77-86. - doi: $10.2307 / 3545517$

Eriksson G (1998). Evolutionary forces influencing variation among populations of Pinus sylvestris. Silva Fennica 32: 173-184. - doi: 10.1421 4/sf.694

Eriksson G (2001). Conservation of noble hardwoods in Europe. Canadian Journal of Forest Research 31: 577-587. - doi: 10.1139/x00-134 Eriksson G, Jonsson A, Lauteri M, Pliura A (2005). Genetic variation in drought response of Castanea sativa Mill. Seedlings. Acta Horticulturae 693: 247-254. - doi: 10.17660/ActaHortic.2005. 693.30

Farquhar GD, Ehleringer JR, Hubick KT (1989). Carbon isotope discrimination and photosynthesis. Annual Review of Plant Physiology and Plant Molecular Biology 40: 503-537. - doi: 10.1146/annurev.pp.40.060189.002443

Flexas J, Bota J, Galmes J, Medrano H, RibasCarbo M (2006). Keeping a positive carbon balance under adverse conditions: responses of photosynthesis and respiration to water stress. Physiologia Plantarum 127: 343-352. - doi: 10.1111 /j.1399-3054.2006.00621.x

Flexas J, Bota J, Loreto F, Cornic G, Sharkey TD (2004). Diffusive and metabolic limitations to photosynthesis under drought and salinity in $C_{3}$ plants. Plant Biology 6: 269-279. - doi: 10.1055/s2004-820867

García-Plazaola JI, Becerril JM (2000). Photoprotection mechanisms in European beech (Fagus sylvatica L.) seedlings from diverse climatic origins. Trees 14: 339-343. - doi: 10.1007/PLoooog 773

Chalambor CK, McKay JK, Carrol SP, Reznick DN (2007). Adaptive versus non-adaptive phenotypic plasticity and the potential for contemporary adaptation in new environments. Func- 
tional Ecology 21: 394-407. - doi: 10.1111/j.13652435.2007.01283.x

Gratani L, Pesoli P, Crescente MF, Aichner K, Larcher W (2000). Photosynthesis as a temperature indicator in Quercus ilex L. Global and Planetary Change 24 (2): 153-163. - doi: 10.1016/ Sog21-8181(99)00061-2

Griffin JJ, Ranney TG, Pharr DM (2004). Heat and drought influence photosynthesis, water relations, and soluble carbohydrates of two ecotypes of redbud (Cercis canadensis). Journal American Society of Horticultural Sciences 129 (4): 497-502.

Guo Y-P, Zhou H-F, Zhang L-C (2006). Photosynthetic characteristics and protective mechanisms against photooxidation during high temperature stress in two citrus species. Scientia Horticulturae 108: 260-267. - doi: 10.1016/j.scien ta.2006.01.029

Hamrick JL, Godt MJW (1989). Allozyme diversity in plant species. In: "Plant Population Genetics, Breeding and Genetic Resources" (Brown AHD, Clegg MT, Kahler AL, Weir BS eds). Sinauer Associates, Sunderland, MA, USA, pp. $43-63$.

Hsiao TC (1973). Plant responses to water stress. Annual Review of Plant Physiology 24: 519-570. - doi: 10.1146/annurev.pp.24.060173.002511 Huntley B, Birks HJB (1983). An atlas of past and present pollen maps of Europe: 0-13,000 years ago. Cambridge University Press, Cambridge, UK, pp. 667.

Irvine J, Perks MP, Magnani F, Grace J (1998). The response of Pinus sylvestris to drought: stomatal control of transpiration and hydraulic conductance. Tree Physiology 18 (6): 393-402. doi: 10.1093/treephys/18.6.393

Jajic I, Sarna T, Strzalka K (2015). Senescense, stress, and reactive oxygen species. Plants 4: 393-411. - doi: 10.3390/plants4030393

Jensen JS, Hansen JK (2010). Genetic variation in response to different soil water treatments in Quercus robur L. Scandinavian Journal of Forest Research 25: 400-411. - doi: 10.1080/02827581.20 10.512873

Kattenberg F, Giorgi F, Grassl H, Meehl GA, Mitchell JFB, Stouffer RJ, Tokioka T, Weaver AJ, Wigley TML (1996). Climate models - projections of future climate. In: "Climate change 1995, The Science of Climate Change" (Houghton JT, Meira Filho LG, Callander BA, Harris N, Kattenberg A, Maskell K eds). Cambridge University Press, Cambridge, UK, pp. 289-357.

Kellomäki S, Wang KY (2001). Growth and resource use of birch seedlings under elevated carbon dioxide and temperature. Annals of Botany 87: 669-682. - doi: 10.1006/anbo.200 1.1393

Klein I, Esparza G, Weinbaum SA, DeJong TM (2001). Effects of irrigation deprivation during the harvest period on leaf persistence and function in mature almond trees. Tree Physiology 21 (14): 1063-1072. - doi: 10.1093/treephys/ 21.14.1063

Kleinschmit J, Svolba J, Rau HM, Weisgerber H (1996). The IUFRO Abies grandis provenance experiment in Germany. Results at age 18/19. Silvae Genetica 45 (5-6): 311-317.

Koskela J, Lefèvre F (2013). Genetic diversity of forest trees. In: "Integrative approaches as an opportunity for the conservation of forest bio- diversity" (Kraus D, Krumm F eds). European Forest Institute, Joensuu, Finland, pp. 232-241.

Kramer GF, Norman HA, Krizek DT, Mirecki RM (1991). Influence of UV-B radiation on polyamines, lipid peroxidation and membrane lipids in cucumber. Phytochemistry 30: 2101-2108. doi: 10.1016/0031-9422(91)83595-C

Laloi C, Stachowiak M, Pers-Kamczyc E, Warzych E, Murgia I, Apel K (2007). Cross-talk between singlet oxygen- and hydrogen peroxide-dependent signalling of stress responses in Arabidopsis thaliana. Proceedings of the National Academy of Sciences USA 104 (2): 672-677. - doi: 10.1073/pnas.0609063103

Larcher WP (1995). Physiological plant ecology. Springer-Verlag, NY, USA, pp. 506.

Lauteri M, Monteverdi MC, Scartazza A, Augusti A, Brugnoli E, Spaccino L, Cherubini M (1997a). Stable isotope and forest ecophysiology. Two case studies concerning: a) adaptation of Castanea sativa Mill. to contrasting environments; b) seasonal variation of water use efficiency within and among plant communities of a Mediterranean coastland ecosystem. SISEF Proceedings 1: 303-307.

Lauteri M, Scartazza A, Guido MC, Brugnoli E (1997b). Genetic variation in photosynthetic capacity, carbon isotope discrimination and mesophyll conductance in provenances of Castanea sativa adapted to different environments. Functional Ecology 11: 675-683. - doi: 10.1046/j. 1365-2435.1997.00140.x

Lauteri M, Monteverdi MC, Sansotta A, Kücük M, Cherubini M, Spaccino L, Villani F (1999). Adaptation to drought in European chestnut: evidences from a hybrid zone and from controlled crosses between drought and wet adapted populations. In: Proceedings of " 2 nd International Symposium on Chesnut" (Salesse G ed). Acta Horticulturae 494: 345-353. - doi: 10.176 6o/ActaHortic.1999.494.53

Lauteri M, Pliura A, Monteverdi M-C, Brugnoli E, Villani F, Eriksson G (2004). Genetic variation in carbon isotope discrimination in six European populations of Castanea sativa Mill. originating from contrasting localities. Journal of Evolutionary Biology 17 (6): 1286-1297. - doi: 10.1111/j. 1420-9101.2004.00765.x

Li C, Ren J, Luo J, Lu R (2004). Sex-specific physiological and growth responses to water stress in Hippophae rhamnoides L. populations. Acta Physiologiae Plantarum 26: 123-129. - doi: 10.1007/s11738-004-0001-3

Liang Z, Yang J, Shao H, Han R (2006). Investigation on water consumption characteristics and water use efficiency of poplar under soil water deficits on the Loess Plateau. Colloids and Surfaces B: Biointerfaces 53 (1): 23-28. - doi: 10.1016/j.colsurfb.2006.07.008

Liu X, Fan Y, Long J, Wei R, Kjelgren R, Gong C, Zhao J (2013). Effects of soil water and nitrogen availability on photosynthesis and water use efficiency of Robinia pseudoacacia seedlings. Journal of Environmental Sciences 25 (3): 585595. - doi: 10.1016/S1001-0742(12)60081-3

Llorens L, Penuelas J, Filella I (2003). Diurnal and seasonal variations in the photosynthetic performance and water relations of two co-occurring Mediterranean shrubs, Erica multiflora and Globularia alypum. Physiologia Plantarum 118 (1): 84-95. - doi: 10.1034/j.1399-3054.2003.0010
1.X Ma F, Xu TT, Ji MF, Zhao CM (2014). Differential drought tolerance in tree populations from contrasting elevations. AoB PLANTS 6: plu69. doi: 10.1093/aobpla/plu069

Matyssek R, Günthard-Goerg MS, Saurer M, Keller $\mathrm{T}$ (1992). Seasonal growth, delta ${ }^{13} \mathrm{C}$ in leaves and stem, and phloem structure of birch (Betula pendula) under low ozone concentrations. Trees 6: 5-13. - doi: 10.1007/BFo0226583 Medrano H, Tomas M, Martorell S, Flexas J, Hernandez E, Rossello J, Pou A, Escalona J-M, Bota $J$ (2015). From leaf to whole-plant water use efficiency (WUE) in complex canopies: limitations of leaf WUE as a selection target. The Crop Journal 3: 220-228. - doi: 10.1016/j.cj.2015. 04.002

Mitchell JFB, Manabe S, Mlesho V, Tokioka T (1990). Equilibrium climate change and its implications for future. In: "Climate Change" (Houghton JT, Jenkins GT, Ephaums JJ eds). Cambridge University Press, Cambridge, UK, pp. 131-175.

Monclus R, Dreyer E, Villar M, Delmotte FM, Delay D, Petit JM, Barbaroux C, Thiec DL, Bréchet C, Brignolas F (2006). Impact of drought on productivity and water use efficiency in 29 genotypes of Populus deltoides $\times$ Populus nigra. New Phytologist 169: 765-777. - doi: 10.1111/j. 1469-8137.2005.01630.x

Morais RR, Carvalho Goncalves JF, Santos Junior UM, Dunisch O, Santos ALV (2007). Chloroplastid pigment contents and chlorophyll a fluorescence in Amazonian tropical three species. Revista Arvore 31 (5): 959-966. - doi: 10.1590/So1 00-67622007000500020

Muraoka H, Tang Y, Terashima I, Koizumi H, Washitani I (2000). Contributions of diffusional limitation, photoinhibition and photorespiration to midday depression of photosynthesis in Arisaema heterophyllum in natural high light. Plant, Cell and Environment 23 (3): 235-250. doi: 10.1046/j.1365-3040.2000.00547.x

Ni BR, Pallardy SG (1991). Response of gas exchange to water stress in seedlings of woody angiosperms. Tree Physiology 8: 1-9.

Norby RJ, Wullschleger SD, Gunderson CA, Johnson DW, Ceulemans R (1999). Tree responses to rising $\mathrm{CO}_{2}$ in field experiments: implications for the future forest. Plant, Cell and Environment 22: 683-714. - doi: 10.1046/j.1365-3040. 1999.00391.x

Pallardy SG, Kozlowski TT (1981). Water relations of Populus clones. Ecology 62 (1): 159-169. - doi: 10.2307/1936679

Petrokas R, Pliura A (2014). Persistence of progenies of Wild Cherry (Prunus avium L.) at Northern limit of natural distribution range in relation to transfer to Lithuania. Baltic Forestry 20 (1): 58-68. [online] URL: http://www.researchgate. net/publication/262599960

Pianka ER (1978). Evoliutionary Ecology. Harper and Row, NY, USA, pp. 399.

Pliura A, Eriksson G (2002). Genetic variation in juvenile height and biomass of open pollinated families of six Castanea sativa Mill. populations in a $2 \times 2$ factorial temperature $x$ watering experiment. Silvae Genetica 51 (4): 152-160. [online] URL: http://www.researchgate.net/publica tion/262599827

Pliura A, Kundrotas V (2002). Genetic variation in 
adaptive traits and ecological sensitivity of black alder. Baltic Forestry 8 (2): 8-21. [online] URL: http://www.researchgate.net/profile/2626 00145

Pliura A, Baliuckas V (2007). Genetic variation in adaptive traits of progenies of Lithuanian and western European populations of Fraxinus excelsior L. Baltic Forestry 13 (1): 28-38. [online] URL: http://www.researchgate.net/publication/ 262600118

Pliura A, Baliuckiene A, Baliuckas V (2008). Phenogenetic response of silver birch populations and half-sib families to elevated ozone and ultraviolet-B radiation at juvenile age. Environmental Pollution 156: 152-61. - doi: 10.1016/j.env pol.2007.12.023

Pliura A, Lygis V, Marčiulyniene D, Suchockas V, Bakys R (2016). Genetic variation in susceptibility of Fraxinus excelsior half-sib families to Hymenoscyphus fraxineus following simulated spring frost and summer drought treatments. iForest - Biogeosciences and Forestry 8: 12-22. doi: 10.3832/ifor1514-008

Reddy AR, Chaitanya KV, Vivekanandan M (2004). Drought-induced responses of photosynthesis and antioxidant metabolism in higher plants. Journal of Plant Physiology 161: 11891202. - doi: 10.1016/j.jplph.2004.01.013

Rhodenbaugh EJ, Pallardy SG (1993). Water stress, photosynthesis and early growth patterns of cuttings of three Populus clones. Tree Physiology 13: 213-26. - doi: 10.1093/treephys/ 13.3.213

Sabin TE, Stafford SG (1990). Assessing the need for transformation of response variables. Forest Research Laboratory, Oregon State University, Corvallis, OR, USA, Special Publication No. 20. pp. 31.

SAS Institute Inc. (2016). SAS ${ }^{\circledR}$ Analytics Pro 12. 1, 9. 3. SAS Institute Inc, Cary, NC, USA. [online] URL: http://support.sas.com/documentation/1 21/

Schwanz P, Polle A (2001). Differential stress responses of antioxidative system to drought in pendunculate oak (Quercus robur) and maritime pine (Pinus pinaster) grown under high $\mathrm{CO}_{2}$ concentrations. Journal of Experimental Botany 52 (354): 133-143. - doi: 10.1093/jexbot/52.35 4.133

Shah A (2015). Climate change and global warming introduction. Global Issues, Web site. [online] URL: http://www.globalissues.org/arti cle/233/climate-change-and-global-warming-in troduction

Shukla GK (1972). Some statistical aspects of partitioning genotype-environment components of variability. Heredity 29: 237-245. - doi: 10.1038 /hdy.1972.87

Skre O (1991). Growth experiments with seedlings of mountain birch (Betula pubescents Ehrh.) and lowland birch (Betula pendula Roth.) grown at varying temperature, light and day length. Communications SkogForsk 44.6, pp. 41.

Sofo A, Dichio B, Xiloyannis C, Masia A (2004). Effects of different irradiance levels on some antioxidant enzymes and on malondialdehyde content during rewatering in olive tree. Plant Science 166: 293-302. - doi: 10.1016/j.plantsci.
2003.09.018

Song Y, Chen Q, Ci D, Shao X, Zhang D (2014). Effects of high temperature on photosynthesis and related gene expression in poplar. BMC Plant Biology 14: 111-130. - doi: 10.1186/1471-222914-111

Souza RP, Machado EC, Silva JAB, Lagoa AMMA, Siliveira JAG (2004). Photosynthetic gas exchange, chlorophyll flourescence and some associated metabolic changes in cowpea (Vigna unguiculata) during water stress and recovery. Environmental Experimental Botany 51: 45-56. doi: 10.1016/S0098-8472(03)00059-5

Strong T, Hansen EA (1991). Response of three Populus species to drought. Research Paper NC-302, USDA Forest Service, North Central Forest Experiment Station, St. Paul, MN, USA, pp. 9.

Stojnić S, Pekač S, Kebert M, Pilipović A, Stojanović D, Stojanović M, Orlović S (2016). Drought effects on physiology and biochemistry of pedunculate oak (Quercus robur L.) and hornbeam (Carpinus betulus L.) saplings grown in urban area of Novi Sad, Serbia. South-east European Forestry 7 (1): 57-63.

Tezara W, Lawlor DW (1995). Effects of water stress on the biochemistry and physiology of photosynthesis in sunflower. In: "Photosynthesis: From Light to Biosphere" (Mathis P ed). Vol. IV. Kluwer Academic Publidhers, Dordrecht-Boston-London, pp. 625-628.

Topić M, Borišev M, Orlović S, Tomičić M, Zupunski M, Nikolić N, Pajević S, Krstić B, Pilipović A (2013). Clonal differences of black poplar cuttings for morphophysiological and biochemical responses to soil water deficits. The Journal of Animal and Plant Sciences 23 (6): 1725-1732.

Tschaplinski TJ, Tuskan GA, Gunderson CA (1994). Water-stress tolerance of black and eastern cottonwood clones and four hybrid progeny. I. Growth, water relations, and gas exchange. Canadian Journal of Forest Research 24 (2): 364-371. - doi: 10.1139/×94-049

Turnbull MH, Whitehead D, Tissue Tet D (2002). Photosynthetic characteristics in canopies of Quercus rubra, Q. pirinus and Acer rubrum differ in response to soil water availability. Oecologia 130: 515-524. - doi: 10.1007/s00442-001-0842-z Velikova V, Yordanov I, Edreva A (2000). Oxidative stress and some antioxidant systems in acid rain-treated bean plants. Plant Science 151: 59-66. - doi: 10.1016/S0168-9452(99)00197-1 Veljovic-Jovanovic S, Noctor G, Foyer CH (2002). Are leaf hydrogen peroxide concentrations commonly overestimated? The potential influence of artefactual interference by tissue phenols and ascorbate. Plant Physiology and Biochemistry 40: 501-507. - doi: 10.1016/S0981-9428 (02)01417-1

Villani F, Pigliucci $M$, Lauteri $M$, Cherubini $M$, Sun O (1992). Congruence between genetic, morphometric and physiological data on differentiation of Turkish chestnut (Castanea sativa Mill.). Genome 35 (2): 251-256. - doi: 10.1139/g92-038

Villani F, Sansotta A, Cherubini M, Cesaroni D (1999). Genetic structure of natural populations of Castanea sativa in Turkey: evidence of a hybrid zone. Journal of Evolutionary Biology 12: 233-244. - doi: 10.1046/j.1420-9101.1999.00033.x
Wahid A, Gelani S, Ashraf M, Foolad MR (2007). Heat tolerance in plants: an overview. Environmental and Experimental Botany 61 (3): 199223. - doi: 10.1016/j.envexpbot.2007.05.011 Weiser F (1995). Beitrag zur Existenz von Okotypen bei Gemeiner Esche (Fraxinus exelsior L.) [Studies into the existence of ecotypes of ash (Fraxinus excelsior)]. Forstliche Forschungsanstalt Eberswalde e.V., Forstarchiv 66 (6): 251257. [in German]

Weisgerber H (1974). First results of progeny test with Alnus glutinosa (L.) Gaertn. after controlled pollination. In: Proceedings of the Joint IUFRO Meeting S02.04: 1-3 Session VI, Stockholm, Sweden, pp. 423-438.

Wellburn AR (1994). The spectral determination of chlorophylls a and b, as well as total carotenoids, using various solvents with spectrophotometers of different resolution. Journal of Plant Physiology 144: 307-313. - doi: 10.1016/S01 76-1617(11)81192-2

Wikberg J, Ogren E (2007). Variation in drought resistance, drought acclimation and water conservation in four willow cultivars used for biomass production. Tree Physiology 27: 13391346. - doi: 10.1093/treephys/27.9.1339

Wricke G (1962). Über eine Methode zur Erfassung der ökologischen Streubreite in Feldversuchen [About a method for detection of environmental variation range in field trials]. $Z$. Pflanzenzucht 47: 92-96. [in German]

Xu X, Yang F, Xiao X, Zhang S, Korpelainen H, Li C (2008). Sex-specific responses of Populus cathayana to drought and elevated temperatures. Plant, Cell and Environment 31 (6): 850-860. doi: 10.1111/j.1365-3040.2008.01799.x

Yang F, Miao LF (2010). Adaptive responses to progressive drought stress in two poplar species originating from different altitudes. Silva Fennica 44 (1): 23-37.

Yin C, Peng Y, Zang R, Zhu Y, Li C (2005). Adaptive responses of Populus kangdingensis to drought stress. Physiologia Plantarum 123: 445451. - doi: 10.1111/j.1399-3054.2005.00477.x

Zhang X, Wollenweber B, Jiang D, Liu F, Zhao J (2008). Water deficits and heat shock effects on photosynthesis of a transgenic Arabidopsis thaliana constitutively expressing ABP9, a bZIP transcription factor. Journal of Experimental Botany 59 (4): 839-848. - doi: 10.1093/jxb/erm3 64

Zhang X, Wu N, Li C (2005). Physiological and growth responses of Populus davidiana ecotypes to different soil water contents. Journal of Arid Environments 60: 567-579. - doi: 10.1016/ j.jaridenv.2004.07.008

Zhang X, Zang R, Li C (2004). Population differences in physiological and morphological adaptations of Populus davidiana seedlings in response to progressive drought stress. Plant Science 166: 791-797. - doi: 10.1016/j.plantsci.2003. 11.016

Zhao XX, Huang LK, Zhang XQ, Li Z, Peng Y (2014). Effects of heat acclimation on photosynthesis, antioxidant enzyme activities, and gene expression in Orchardgrass under heat stress. Molecules 19: 13564-13576. - doi: 10.339 o/molecules190913564 